\title{
Children's Environment in Brazil: From Domestic (Indoor) to Regional Threats
}

\author{
Norma Helena Perlroth ${ }^{1,2}$, Christina Wyss Castelo Branco ${ }^{2,3}$ \\ ${ }^{1}$ University Hospital Gaffrée Guinle, Department of Pediatrics, Pediatric Emergency Care, Federal University of the State of Rio de \\ Janeiro, RJ, Brazil.
}

${ }^{2}$ Doctoral Program in Nursing and Biosciences, Federal University of the State of Rio de Janeiro, RJ, Brazil.

${ }^{3}$ Department of Zoology, Institute of Biosciences, Federal University of the State of Rio de Janeiro, RJ, Brazil.

Received: March 15, 2017; Accepted: April 1, 2017; Published: July 17, 2017

*Corresponding author: Norma H. Perlroth, University Hospital Gaffrée Guinle, Department of General Medicine - Pediatrics, Federal University of the State of Rio de Janeiro, Rua Mariz e Barros, 775, CEP: 20270-002, Rio de Janeiro - RJ - Brazil. Phone: +55 21 22397352; E-mail: norma.perlroth@gmail. com

\begin{abstract}
Background: This research has been carried out with Brazilian children living in heterogeneous environments and vulnerable to multiple factors that can interact and influence the likelihood of their exposure to harmful agents. A review focused on the impacts of threats from domestic indoor to outdoor environment on this children's health was held. The assessment was based on scientific research produced from 1999 to 2013 and conducted exclusively in Brazil. We grouped the studies in three, the first one, considered as Home Life (HL) refers to the effects on children's health of hazardous components related to the household area, related to two subthemes: unintentional ingestion of chemical compounds and home environmental pollution. Medications, cleaning products and pesticides were the most common agents of poisoning and parental smoking and the use of wood stove for cooking were directly responsible for respiratory diseases. The second group called Social (S) correlates socio-environmental factors focused on childhood diarrhea, geo-helminthiasis and urban sanitation conditions. Precarious households, lack of sewage system, improper waste management enhanced the importance of watertransmitted illness in children health. The third group, considered as Regional (R), exposes environmental chemical contaminations and biological agents as regional risk factors to child morbidity-mortality. Air pollution due to increased levels of $\mathrm{PM} 10, \mathrm{SO}_{2}$ and $\mathrm{O}_{3}$ were associated with higher prevalence of respiratory diseases, which can be also influenced by the region seasonality. Agrochemicals, mercury, arsenic and in special lead were considered potential risk factors to children's health throughout the country. Infectious tropical diseases and accidental contacts with biological agents of pathologies for children were related to regional peculiarities. This review highlights that the occurrence of environmental exposed diseases in Brazilian children is extremely serious and not random, and it is possible to establish causal links and, thus, to define protection factors that must be considered by stakeholders and government to improve the quality of life of that age bracket.
\end{abstract}

Key words: Child health; Environmental risks; Brazil; Developing countries;

\section{Introduction}

In the globalized world of the 21st century, most of the child population has been stimulated by many opportunities and challenges, but they have also found huge barriers in relation to their health, development and well-being in the form of environmental threats [1]. According to international data, in 2015, approximately 5.9 million children died under age five, in an estimated rate of 16,000 deaths per day, mostly from diseases that are promptly preventable and treatable with tested, costeffective and quality-delivered interventions [2]. The number of under-five deaths over the past two decades is astounding: between 1990 and 2015, nearly 230 million children worldwide died before their fifth birthday, more than today's population of Brazil, the world's fifth most populous country [3]. But the good news is that nowadays, under-five mortality rate has decreased. In 2015, there were 19,000 fewer deaths of children in this age group than in 1990, the reference year for measuring progress [2].

The survival of every child is still an unpostponable priority and varies enormously depending on where a child was born and grows. Environmental risk factors, such as air, water and soil pollution, chemical exposures and climate change, contribute to more than 100 diseases and injuries [4]. In low and mediumincome nations, the most commons environmental disorders, constituting major public health problem, are the lack of potable water and sanitation access, resulting in waterborne diseases, such as diarrhea [5] and lower respiratory tract infections. While in developed countries, the most prevalent diseases are allergy and asthma [6]. Researchers have been analyzing the way the environment can change the expression of the genes and how that can cause diseases. Medications, pesticides, air pollutants, chemicals, heavy metals, hormones, nutrition products and behaviors can change the genetic expression by way of a huge amount of gene regulatory mechanisms [7]. 
Important information regarding accidental poisonings and intoxications is that children, by nature, are curious, and can open, eat and drink what adults know to be dangerous agents. Parents and caretakers, by negligence or lack of information, keep medications and domestic products in inappropriate places, underestimating what children can do. The habit of selfmedication can lead to a higher intake of medication, which makes it easier for those agents to reach domiciles, where children can potentially get access and be poisoned by them [8].

Pollution in the indoor environment is a multifaceted mixture of agents migrating indoors from the outdoor air in addition to agents generated by indoor sources [9]. Tobacco smoke is a threat to children's health with adverse effects on their pulmonary function $[10,11]$. The smoke of tobacco is full of exogenous mutagenic and cancerous agents $[12,13]$.

Data from the WHO [14] shows secondary domestic pollution due to the burning of solid fuel (wood, coal, manure, crop residue) on fires or traditional stoves as one of the top ten risks to health in the world, affecting children directly. The inefficient burn of those solid fuels releases a dangerous mixture of thousands of substances such as particulate matter, carbon monoxide, nitrous oxide, sulfuric oxides, formaldehyde, hydrocarbons and polycyclic organic matter, which includes carcinogenic substances such as benzopyrene [15]. The amount of smoke women and their young children inhale can be equal to that of two packs of cigarettes a day [16]. Through the air, the smoke from forest fires is made up of gases, such as water vapor, molecular nitrogen, $\mathrm{SO}_{2}, \mathrm{CO}$, $\mathrm{CO}_{2}, \mathrm{CH}_{4}$, among others, and ash micro particles [17]. The total suspended particulate matter, inhalable particulate matter and nitrogen dioxide can cause, on children who live near where fires take place, side effects through a combination of harm caused by heat, pulmonary irritation, oxygen deprivation (asphyxia) and poisoning [17].

The contamination of the environment by chemical agents (aluminum, mercury, pesticides, petroleum hydrocarbons, silver, vinyl chloride, arsenic, cyanide, benzopyrene) resulting from untreated water; industrial activities; mineral exploration and agriculture can be responsible for the increase in congenital malformations, asthma, cancer, disruption of the endocrine system, neurological and behavioral disorders in children $[18,19]$. The physical agents that can also present hazards to children's health are sediment resuspension, turbidity, corrosive materials, and water offensive odors and incompatible color [20].

This vulnerability children have to environmental hazards occurs because the child population is a peculiar demographic group that shows very specific physiological characteristics: it is during the early childhood that several biological systems, like the brain, lung structure and the immune system develop and mature [9]. Toxic gases can compromise pulmonary function and neurodevelopment or exacerbate preexisting conditions, and children born prematurely can be more vulnerable to environmental hazards due to pulmonary immaturity at birth [21]. Children ingest more water and food and breathe more air by body weight unit than adults. Infants, during the first 6 months, ingest seven times more water, and, at pre-school age (1 to 5 years of age), from three to four times more food by kilogram of body weight than the average adult [22]. The intake of air of resting infants is twice as high in average adults [23]. Peculiar habits, such as constantly putting their hand in their mouth [9] and playing and crawling in the ground also contribute to a higher exposure. Thus, agents present in the air, the water, the ground and in food have a higher probability to be absorbed by children than by adults.

Facing these facts, the authors conducted a review on the relationship between exposure to environmental pollutions and diseases in Brazilian children. Brazil is a large country, being the fifth in overall surface area, and has a wide regional diversity in terms of biomes and socioeconomic development. Several unfavorable environmental conditions and toxic substances present in several regions of Brazil, but independent of socioeconomic and cultural differences and occurring in rural and industrialized areas, are a threat to the lives of children, and a prolonged exposure could compromise the survival of their generations and others to come. The scope of the review covers indoor and outdoor pollutants for the entire Brazil from 1999 to 2013. The main knowledge and environmental issues acting on children health were identified and discussed, as well the remaining gaps.

\section{Material and Methods}

An ample bibliographic revision was carried out using the following electronic databases: MedLine, PubMed, Scielo, Lilacs and BDENF (Nursing Database) were used to retrieve relevant articles in the Brazilian literature published from 1999 to 2013. Besides the use of the aforementioned databases, a research was also carried out on the websites of organizations such as the World Health Organization - WHO, the United Nations Children's Emergency Fund - UNICEF the Pan American Health Organization - PAHO in order to update information found on the selected documents. Texts published on the website of Brazilian organizations of research in health and human geography such as Brazilian Institute of Geography and Statistic (IBGE) were also used. The databases were searched separately and then combined to eliminate duplication.

The search strategy involved terms as referred to Brazilian Virtual Health Library/Health Sciences Descriptors (DeCS) that includes, concomitantly, the Portuguese, the English and Spanish languages. The criteria for inclusion were: articles with data from research carried out exclusively in Brazil, published in national and evaluated according to criteria of journal classification in the QUALIS system of CAPES (Brazilian Federal Agency for the Improvement of Higher Education) (https://sucupira. capes.gov.br/) as A1-A2-B; international journals, available access to the full text of articles in the databases and whose methodology allowed for the discovery of evidence regarding the environmental influence in the health of children. The following types of papers were excluded: case study, dissertations, theses and guidelines. The research strategy included the following descriptors: "children health", "environmental risks", "health 
vulnerability", "accident prevention", "poisoning", "sanitizing products", "pesticide exposure", "environmental pollutants", "air pollution", "tobacco smoke pollution", "diarrhea infantile", "basic sanitation" "parasitic diseases", "water pollution", "environmental health", as well as Boolean operators (AND, OR and NOT) made available by databases.

We grouped the studies in three, as follow: The first group, which we will call HOME LIFE (HL), refers to the possible effects on children's health hazardous components related to the household and its surrounding area might have, such as unintentional injuries caused by chemical compounds and home environmental pollution. The second group, called SOCIAL (S), correlates sanitation and socio-environmental factors, such as diarrheal diseases and soil-transmitted parasites and their influence on children's health. The third group, REGIONAL (R), exposes the regional environmental physical, chemical and biological agents as a risk factor to child morbidity and mortality. The references of the identified articles are shown in supplementary material.

\section{Results}

Over 448 studies were reviewed in this paper to identify emerging patterns and gaps in the children's environmental health field. After exclusions, the search performed retrieved 127 articles (Fig.1). In the HL group, there were 22 articles, in the S category 49 articles were raised and in the R group, there were analyzed 56 studies.

\section{Geographic distribution}

In order to have an overview of the geographic distribution of the studies, we considered for the analysis the five geographic regions of Brazil: North (N), Northeast (NE), Central-West (CW), Southeast (SE) and South (S). The N Region, takes up $45.25 \%$ of the absolute area of the country, has an estimated population of $17,186,877$ people and is the region with the lowest population density [24]. The NE Region has $18.2 \%$ of the country's area and an estimated population of 56,241,859 inhabitants [24]. The CW Region has $18.86 \%$ of the country's area and an estimated population of 15,251,494 inhabitants [24]. The SE Region has 10.85\% of the country's area and an estimated population of $85,241,641$ inhabitants. This region has the highest Gross Domestic Product - GDP of Brazil [22]. The S Region has $6.77 \%$ of the country's

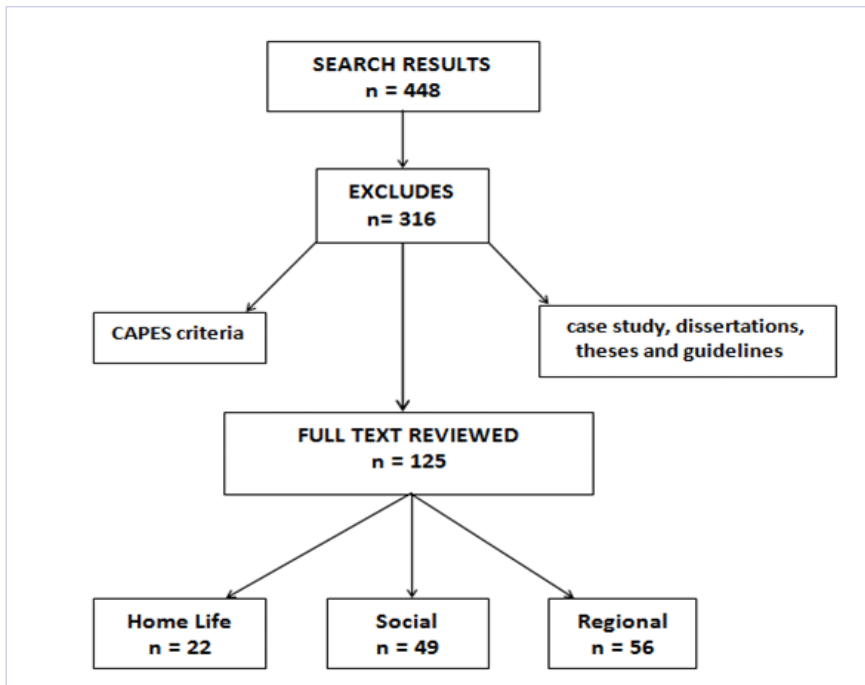

Figure 1: Categorization of studies for analysis. area. It has an estimated population of 29,041,466 [24], and the one with the highest Human Development Index - HDI [25]. It can be observed that $42 \%$ of the studies were carried out in the SE Region, which relates the richest region with the number of research.

The SE Region, predominate in the majority of papers. In the $\mathrm{N}$ Region, the majority of the articles deal with one subtheme of the R2 group, with relation to peculiar questions of the region, which comprehends most of the Amazon Basin, with its local particularities, such as mining, forest fires, and malaria cases, among others. The CW Region, despite holding the country's capital, has the fewest number of papers. Although Brazil is a federative union, few studies included two or more regions in their researches showing low number of integrated research on children's environment in the country.

\section{Home Life}

In this section, 22 articles related to two subthemes were selected: "unintentional ingestion of chemical compounds" and "home environmental pollution".

In the first subtheme, 9 articles were used (Tab. I).

\begin{tabular}{|c|c|c|c|c|c|c|}
\hline \multicolumn{7}{|c|}{ Unintentional ingestion of chemical compounds } \\
\hline Reference & Purpose & Type of Study & Health Efects & Age & Region & Outcomes \\
\hline $\begin{array}{c}\text { Tavares et al. } \\
(2013)[26]\end{array}$ & $\begin{array}{l}\text { to analyze the risk } \\
\text { factors associated } \\
\text { with poisoning in } \\
\text { children }\end{array}$ & longitudinal & $\begin{array}{c}\text { acute } \\
\text { intoxication }\end{array}$ & $\begin{array}{c}\text { newborn } \\
-14 y\end{array}$ & S & $\begin{array}{l}\text { Associated factors: male gender and age (from } \\
\text { zero to four years), easier access to drugs at } \\
\text { home and the adult's presence did not prevent } \\
\text { the occurrence of intoxication. }\end{array}$ \\
\hline $\begin{array}{c}\text { Lira et al. (2009) } \\
\text { [27] }\end{array}$ & $\begin{array}{l}\text { to analyze the } \\
\text { intoxication by } \\
\text { pesticides in children, } \\
\text { adolescents and } \\
\text { youngsters }\end{array}$ & longitudinal & $\begin{array}{l}\text { acute } \\
\text { intoxication }\end{array}$ & $\begin{array}{c}\text { newborn } \\
-19 y\end{array}$ & NE & $\begin{array}{c}\text { Associated factors: male gender and age (from } \\
\text { zero to four years); trigger factor: raticides } \\
\text { - as individual accident in children and with } \\
\text { intentional character (attempted suicide) } \\
\text { among teenagers. }\end{array}$ \\
\hline
\end{tabular}




\begin{tabular}{|c|c|c|c|c|c|c|}
\hline $\begin{array}{l}\text { Lessa \& Bochner } \\
\text { (2008) [28] }\end{array}$ & $\begin{array}{l}\text { to identify the main } \\
\text { therapeutic classes } \\
\text { responsible for drug } \\
\text { intoxications related } \\
\text { to the hospitalization } \\
\text { of children }\end{array}$ & longitudinal & $1,21 \%$ lethality & $<1 \mathrm{y}$ & $\begin{array}{l}\mathrm{N}, \mathrm{NE}, \\
\mathrm{CO} \\
\mathrm{SE}, \mathrm{S}\end{array}$ & $\begin{array}{l}\text { Associated factors: male gender and infants } \\
(85 \%) \text {; trigger factor: antiepileptic, sedative- } \\
\text { hypnotic and antiparkinsonism drugs, with } \\
15.2 \% \text { of hospitalizations in children under one } \\
\text { month and } 21.1 \% \text { in infants. }\end{array}$ \\
\hline $\begin{array}{l}\text { Lourenço et al. } \\
\text { (2008) [29] }\end{array}$ & $\begin{array}{l}\text { to describe the } \\
\text { epidemiological } \\
\text { characteristics of all } \\
\text { exogenic poisoning } \\
\text { cases in children }\end{array}$ & longitudinal & $3,84 \%$ lethality & $\begin{array}{c}\text { newborn } \\
-12 y\end{array}$ & $\mathrm{NE}$ & $\begin{array}{l}\text { Associated factor: male gender and age under } \\
\text { five (64.5\%), easier access to drugs at home } \\
\text { (80\%) and parents present in } 57.7 \% \text { of the } \\
\text { incidents; trigger factor: anticonvulsants and } \\
\text { bronchodilators. }\end{array}$ \\
\hline $\begin{array}{l}\text { Siqueira et al. } \\
(2008)[30]\end{array}$ & $\begin{array}{c}\text { to describe the profile } \\
\text { of the acute exogenous } \\
\text { intoxications, among } \\
\text { children }\end{array}$ & cross-sectional & $\begin{array}{l}39.7 \% \text { vomiting } \\
/ \\
20.7 \% \text { sleepiness }\end{array}$ & $0-12 y$ & CO & $\begin{array}{l}\text { Associated factor: male gender and children } \\
(1-3 \text { y), easier access to drugs at home; trigger } \\
\text { factor: drug (34\%), rat poison (14\%) and } \\
\text { chemical products for domestic use (13\%). }\end{array}$ \\
\hline $\begin{array}{l}\text { Martins et al. } \\
(2006)[31]\end{array}$ & $\begin{array}{l}\text { to analyze the } \\
\text { characteristics of } \\
\text { accidental poisoning } \\
\text { among children and } \\
\text { adolescents }\end{array}$ & longitudinal & $\begin{array}{c}17.2 \% \\
\text { hospitalization }\end{array}$ & $0-15 y$ & S & $\begin{array}{c}\text { Associated factor: female gender and } \\
\text { children (1-3 y); trigger factor: drugs } \\
(47.5 \%), \text { pesticides }(14.1 \%) \text { and cleaning } \\
\text { products (11.3\%), with } 17.2 \% \text { of children's } \\
\text { hospitalization. }\end{array}$ \\
\hline $\begin{array}{l}\text { Ramos et al. } \\
(2005)[32]\end{array}$ & $\begin{array}{l}\text { to establish the profile } \\
\text { of poisonings among } \\
\text { children }\end{array}$ & cross-sectional & $\begin{array}{c}\text { acute } \\
\text { intoxication }\end{array}$ & $0-4 y$ & $\mathrm{~S}$ & $\begin{array}{l}\text { Associated factor: male gender and children } \\
(1 \text { y), easier access to drugs at home and the } \\
\text { adult's presence in } 76.2 \% \text { of the incidents; } \\
\text { trigger factor: analgesics. }\end{array}$ \\
\hline $\begin{array}{c}\text { Bucaretchi et al. } \\
\text { (2003) [33] }\end{array}$ & $\begin{array}{l}\text { to study acute } \\
\text { exposure to } \\
\text { imidazoline } \\
\text { derivatives in } \\
\text { children }\end{array}$ & longitudinal & $\begin{array}{c}15 \% \\
\text { asymptomatic }\end{array}$ & $2 \mathrm{~m}-13 \mathrm{y}$ & SE & $\begin{array}{c}\text { Associated factor: female gender and } 21 \\
\text { months of median age. Easier access to drug } \\
\text { in the house. The exposure pathway was oral } \\
\text { and nasal. }\end{array}$ \\
\hline $\begin{array}{l}\text { Matos et al. } \\
(2002)[34]\end{array}$ & $\begin{array}{l}\text { to describe drug } \\
\text { intoxication among } \\
\text { children }\end{array}$ & longitudinal & $0,11 \%$ lethality & $0-4 \mathrm{y}$ & $\begin{array}{l}\text { SE } \\
\text { and } S\end{array}$ & $\begin{array}{l}\text { Associated factor: children (2-3 y); trigger } \\
\text { factor: drugs administration errors and } \\
\text { medicinal use. Analgesics, decongestants, } \\
\text { bronchodilators, antiepileptics and oral } \\
\text { contraceptives were the therapeutic classes } \\
\text { involved, and decongestants, antiepileptics, } \\
\text { antihistamines and expectorants were } \\
\text { associated to cause of death. }\end{array}$ \\
\hline
\end{tabular}

According to the authors, during early childhood, children are very curious and have no idea how dangerous toxic agents can be. The medication was the toxic agent most commonly found in the research with $77.7 \%$ of the studies. Included antiepileptic, sedative-hypnotic and antiparkinsonian drugs [28, 29], bronchodilators [29], imidazole derivatives [33] and painkillers $[32,34]$. There is also the hypothesis of medication poisoning through transplacental transmission and breast-feeding in children less than one month of age [28].

Pesticides were the second toxic agent $(55.5 \%)$ found in the study $[26,27,29,30,31]$, and poisoning was generally accidental in children and intentional in adolescents. In both cases the home was the locus of such occurrences.

Ease of access to those products was essential for selfharm and the adult's presence did not prevent the occurrence of intoxication [26, 29, 30, 32]. Vomiting and somnolence were considered a common clinical manifestation on children seen on hospital units [30] and infant deaths were reported as a complication of acute intoxication to toxic agents [28, 29, 34].

On the subtheme called "home environmental pollution", 13 articles were found (Tab.II). Articles demonstrated the impact of secondhand smoking on children's health since the intrauterine stage, affecting negatively anthropometric measurements (weight, length, and head circumference) of newborns [37, 44]. Parental smoking was also responsible for wheezing babies [35], ear infections and eye irritation [36] and history of respiratory diseases $[42,45,47]$. In the case control studies, children exposed to smoking show higher risk to develop the abovementioned diseases than those who are not exposed [35, 36, 39, 40]. In addition, children living in crowded environments and poor housing conditions play a fundamental role in the causal chain of respiratory diseases $[38,42,46]$. As well, the use of a wood stove for cooking was responsible for a higher occurrence of recurrent wheezing [41]. 


\begin{tabular}{|c|c|c|c|c|c|c|}
\hline \multicolumn{7}{|c|}{ Home environmental pollution } \\
\hline Reference & Purpose & Type of Study & Health Efects & Age & Region & Outcomes \\
\hline $\begin{array}{c}\text { Schvartsman } \\
\text { et al. (2013) } \\
{[35]}\end{array}$ & $\begin{array}{l}\text { to investigate parental } \\
\text { smoking patterns and their } \\
\text { association with wheezing in } \\
\text { children }\end{array}$ & cross-sectional & wheezing & $6-23 m$ & SE & $\begin{array}{c}\text { Associated factors: male gender, age }<2 \\
\text { y, exposure to cigarettes smoking in the } \\
\text { households of cases indicated that the risk of } \\
\text { wheezing was dose dependent. }\end{array}$ \\
\hline $\begin{array}{l}\text { Coelho et al. } \\
\text { (2012) [36] }\end{array}$ & $\begin{array}{l}\text { to investigate if there is a } \\
\text { relation between respiratory } \\
\text { diseases and passive tobacco } \\
\text { smoking among children }\end{array}$ & cross-sectional & $\begin{array}{l}\text { otitis / wheeze / } \\
\text { coryza }\end{array}$ & $\begin{array}{l}\text { newborn } \\
-4 y\end{array}$ & SE & $\begin{array}{l}\text { Associated factor: children under two years; } \\
\text { trigger factor: exposure to secondhand smoke } \\
\text { - } 17.39 \% \text { of the passive smoker group had ear } \\
\text { infections, wheezing, coryza and eye irritation. }\end{array}$ \\
\hline $\begin{array}{l}\text { Zhang et al. } \\
\text { (2011) [37] }\end{array}$ & $\begin{array}{l}\text { to investigate the prevalence } \\
\text { of maternal smoking during } \\
\text { pregnancy and its impact on } \\
\text { anthropometric measurements } \\
\text { of newborns }\end{array}$ & cross-sectional & $\begin{array}{l}\text { reduced } \\
\text { anthropometric } \\
\text { measurements }\end{array}$ & newborn & $\mathrm{CO}$ & $\begin{array}{l}\text { Maternal smoking throughout the entire } \\
\text { pregnancy had negative impact on } \\
\text { anthropometric measurements of newborns } \\
\text { with reduction in the weight, length and head } \\
\text { circumference. }\end{array}$ \\
\hline $\begin{array}{l}\text { Prietsch et al. } \\
\text { (2008) [38] }\end{array}$ & $\begin{array}{l}\text { to determine the prevalence of } \\
\text { acute lower respiratory illness } \\
\text { and to identify associated } \\
\text { factors among children }\end{array}$ & cross-sectional & $\begin{array}{l}\text { wheezing / } \\
\text { pneumonia }\end{array}$ & $<5 y$ & S & $\begin{array}{l}\text { Household crowding and maternal smoking } \\
\text { with a clear dose-response effect and increased } \\
\text { risk of acute lower respiratory tract disease. }\end{array}$ \\
\hline $\begin{array}{l}\text { Casagrande et } \\
\text { al. (2008) [39] }\end{array}$ & $\begin{array}{l}\text { to assess asthma prevalence } \\
\text { and potential risk factors } \\
\text { associated }\end{array}$ & cross-sectional & $\begin{array}{l}\text { eczema / } \\
\text { rhinoconjunctivitis }\end{array}$ & $6-7 y$ & SE & $\begin{array}{l}\text { Associated factor: male gender, smoking mother } \\
\text { during children's first year of life, presence of } \\
\text { eczema and rhinoconjunctivitis. }\end{array}$ \\
\hline $\begin{array}{l}\text { Macedo et al. } \\
\text { (2007) [40] }\end{array}$ & $\begin{array}{l}\text { to evaluate risk factors for } \\
\text { acute respiratory disease } \\
\text { hospitalizations in children }\end{array}$ & cross-sectional & wheezing & $\begin{array}{l}\text { newborn } \\
-11 \mathrm{~m}\end{array}$ & S & $\begin{array}{l}\text { Associated factors: male gender and babies } \\
\text { under six months of age, lack of or low maternal } \\
\text { education, previous history of wheezing, early } \\
\text { weaning and maternal smoking. }\end{array}$ \\
\hline $\begin{array}{l}\text { Prietsch et al. } \\
(2006)[41]\end{array}$ & $\begin{array}{l}\text { to study the prevalence of and } \\
\text { major factors associated with } \\
\text { recurrent wheezing in children }\end{array}$ & cross-sectional & wheezing & $0-12 y$ & S & $\begin{array}{l}\text { The use of wood stove was a } 2.5 \text { times higher } \\
\text { risk for the occurrence of recurrent wheezing } \\
\text { compared to those who did not use this type } \\
\text { of stove. }\end{array}$ \\
\hline $\begin{array}{l}\text { Gonçalves- } \\
\text { Silva et al. } \\
\text { (2006) [42] }\end{array}$ & $\begin{array}{l}\text { to identify factors associated } \\
\text { with respiratory disease in } \\
\text { children }\end{array}$ & cross-sectional & $\begin{array}{l}\text { Asthma / } \\
\text { bronchiolitis }\end{array}$ & $<5 y$ & $\mathrm{CO}$ & $\begin{array}{l}\text { Children with lower socioeconomic status and } \\
\text { exposed to household smoking. }\end{array}$ \\
\hline $\begin{array}{l}\text { Gonçalves- } \\
\text { Silva et al. } \\
\text { (2005) [43] }\end{array}$ & $\begin{array}{l}\text { to estimate the prevalence } \\
\text { of exposure to smoking in } \\
\text { households in children to } \\
\text { identify the main determinants } \\
\text { of that exposure }\end{array}$ & cross-sectional & short stature & $<5 y$ & $\mathrm{CO}$ & $\begin{array}{l}\text { Associated factors: female gender, parental } \\
\text { smoking associated with low infant stature even } \\
\text { after adjusting for smoking during pregnancy } \\
\text { and sociodemographic variables. }\end{array}$ \\
\hline $\begin{array}{l}\text { Chatkin \& } \\
\text { Menezes } \\
(2005)[44]\end{array}$ & $\begin{array}{l}\text { to study the prevalence and } \\
\text { risk factors for asthma in a } \\
\text { cohort of children born in } \\
1993 \text { and followed up to the } \\
\text { age of six years }\end{array}$ & longitudinal & $\begin{array}{l}12.8 \% \text { asthma / } \\
\text { allergic rhinitis }\end{array}$ & $6-7 y$ & $S$ & $\begin{array}{l}\text { Associated factors: female gender, non-white } \\
\text { skin, asthma in the family, smoking during } \\
\text { pregnancy and allergic rhinitis in children. }\end{array}$ \\
\hline $\begin{array}{c}\text { Carvalho \& } \\
\text { Pereira (2002) } \\
\quad[45]\end{array}$ & $\begin{array}{l}\text { to study the prevalence of } \\
\text { respiratory morbidity among } \\
\text { passive smoking children and } \\
\text { to determine the effects of } \\
\text { environmental tobacco smoke } \\
\text { in the respiratory system }\end{array}$ & cross-sectional & $\begin{array}{l}\text { wheezing / asthma / } \\
\text { dyspnea / pneumonia }\end{array}$ & $<5 y$ & NE & $\begin{array}{l}\text { Associated factors: male gender, parental } \\
\text { smoking and respiratory diseases history. } \\
\text { Regarding the respiratory tract the most } \\
\text { frequent complaints were wheeze, dyspnea, } \\
\text { asthma, bronchitis or pneumonia and rhinitis. }\end{array}$ \\
\hline $\begin{array}{l}\text { Prietsch et al. } \\
\text { (2002) [46] }\end{array}$ & $\begin{array}{l}\text { to study the prevalence of } \\
\text { acute disease of the lower } \\
\text { airways and the role of the } \\
\text { domestic environment and } \\
\text { maternal smoking }\end{array}$ & cross-sectional & acute resp. disease & $<5 y$ & S & $\begin{array}{l}\text { Associated factors: similar distribution } \\
\text { according to age and sex, passive smoking, } \\
\text { living in crowded environments and poor } \\
\text { housing conditions }\end{array}$ \\
\hline $\begin{array}{l}\text { Pereira et al. } \\
(2000)[47]\end{array}$ & $\begin{array}{l}\text { to determine the effects of } \\
\text { second-hand smoke in the } \\
\text { respiratory system in children }\end{array}$ & cross-sectional & $\begin{array}{l}82 \% \text { wheezing / } \\
\text { dyspnea }\end{array}$ & $<5 y$ & NE & $\begin{array}{c}\text { Associated factors: male gender, environmental } \\
\text { tobacco smoke: from } 55.3 \% \text { of passive smoking } \\
\text { children in the study, } 82 \% \text { had respiratory } \\
\text { problems. }\end{array}$ \\
\hline
\end{tabular}




\section{Social - Sanitation and Socio-environmental Factors}

In the second block, 49 articles related to two subthemes were selected: "waterborne diseases" and the "prevalence of intestinal parasites".

Regarding the first subtheme, 22 articles were used (Tab.III). Researchers identified that precarious households [63, 65], the lack of a sewage system $[65,69]$, rudimentary lavatories, lack of a garbage collection $[48,50,53,58,62]$ and the use of no potable water [60] are variables that influence the morbimortality rate of children under 5 years of age due to water-transmitted illnesses, like diarrhea [57]. In this sence, cities with a low Human Development Index (HDI) have the highest mortality coefficients due to diarrheal disease [49] with $20 \%$ of the children in those regions having a deficit of $>2$ standard-deviations for the height/ age index [55], leading these children to chronic malnutrition [62].

\begin{tabular}{|c|c|c|c|c|c|c|}
\hline \multicolumn{7}{|c|}{ Waterborne diseases } \\
\hline Reference & Purpose & $\begin{array}{l}\text { Type of } \\
\text { Study }\end{array}$ & Health Efects & Age & Region & Outcomes \\
\hline $\begin{array}{l}\text { Torres et al. } \\
\text { (2013) [48] }\end{array}$ & $\begin{array}{l}\text { to analyze the } \\
\text { spatial distribution } \\
\text { of morbidity due } \\
\text { to diarrhea among } \\
\text { children and its } \\
\text { relation with lifestyle } \\
\text { conditions }\end{array}$ & longitudinal & $15.5 \%$ hospitalization & $<5 y$ & SE & $\begin{array}{l}\text { the suburbs with the highest DHR- Diarrhea } \\
\text { Hospitalization Ratio - were, in most cases, those } \\
\text { with the highest population agglomerations. }\end{array}$ \\
\hline $\begin{array}{l}\text { Mendes et al. } \\
(2013)[49]\end{array}$ & $\begin{array}{l}\text { to verify the temporal } \\
\text { trends of the } \\
\text { indicators of overall } \\
\text { mortality and hospital } \\
\text { morbidity due to } \\
\text { diarrheal disease in } \\
\text { children }\end{array}$ & $\begin{array}{l}\text { cross- } \\
\text { sectional }\end{array}$ & $\begin{array}{l}80 \% \text { lethality }<1 \mathrm{y} \\
62,6 \% \text { hospitalization }\end{array}$ & $<5 y$ & $\begin{array}{l}\text { N, NE, CO, } \\
\quad \text { SE, S }\end{array}$ & $\begin{array}{l}\text { mortality due to diarrheal disease in Brazil } \\
\text { showed a downwards trend. The Northeast Region } \\
\text { accounted for } 46 \% \text { of hospitalization. }\end{array}$ \\
\hline $\begin{array}{l}\text { Paz et al. } \\
\text { (2012) [50] }\end{array}$ & $\begin{array}{c}\text { to identify the } \\
\text { association between } \\
\text { diarrhea } \\
\text { in children } \\
\text { and children } \\
\text { characteristics, access } \\
\text { to sanitation and } \\
\text { housing conditions }\end{array}$ & $\begin{array}{l}\text { cross- } \\
\text { sectional }\end{array}$ & $\begin{array}{l}\text { hospitalization/ } \\
\text { malnutrition }\end{array}$ & $0-2 y$ & SE & $\begin{array}{c}\text { male gender; age } 4-9 \text { months; the risk of diarrheal } \\
\text { occurrence in children is almost } 15 \text { times greater } \\
\text { than that of children living in good water and } \\
\text { sanitation conditions. }\end{array}$ \\
\hline $\begin{array}{l}\text { Ciaccia et al. } \\
\text { (2012) [51] }\end{array}$ & $\begin{array}{l}\text { to discover the } \\
\text { prevalence of } \\
\text { serological markers } \\
\text { for the hepatitis A } \\
\text { virus among children } \\
\text { and teenagers }\end{array}$ & $\begin{array}{l}\text { cross- } \\
\text { sectional }\end{array}$ & jaundice & $7 m-18 y$ & SE & $\begin{array}{l}\text { female gender; age } 8 \mathrm{y} \text {; children playing in streams, } \\
\text { residence without sewage collection, parents with } \\
\text { low education, and low family income. }\end{array}$ \\
\hline $\begin{array}{l}\text { Markus et al. } \\
\text { (2011) [52] }\end{array}$ & $\begin{array}{l}\text { to determine the } \\
\text { seroprevalence of } \\
\text { hepatitis A (HAV) } \\
\text { in children and to } \\
\text { identify factors } \\
\text { associated with a } \\
\text { history of infection }\end{array}$ & $\begin{array}{c}\text { cross- } \\
\text { sectional }\end{array}$ & positive serology & $1-14 y$ & S & $\begin{array}{l}\text { male gender; use of community refectory, low- } \\
\text { income per capita and indoor crowding. }\end{array}$ \\
\hline $\begin{array}{l}\text { Bellido et al. } \\
(2010) \text { [53] }\end{array}$ & $\begin{array}{l}\text { to determine the } \\
\text { relationship between } \\
\text { the variables for } \\
\text { water conditions, } \\
\text { environmental } \\
\text { sanitation, and } \\
\text { mortality in children } \\
\text { associated with a } \\
\text { group of waterborne } \\
\text { diseases }\end{array}$ & longitudinal & 3.004 deaths & $<5 y$ & $\begin{array}{l}\text { N, NE, CO, } \\
\quad \text { SE, S }\end{array}$ & $\begin{array}{l}\text { inadequate sanitation in the dwelling;modest } \\
\text { economic conditions and low levels of parental } \\
\text { education, major population concentration. }\end{array}$ \\
\hline $\begin{array}{l}\text { Melli \& } \\
\text { Waldman, } \\
\text { (2009) [54] }\end{array}$ & $\begin{array}{l}\text { to analyze the trend } \\
\text { in mortality due } \\
\text { to diarrhea among } \\
\text { children between } 1980 \\
\text { and } 2000\end{array}$ & longitudinal & $94,3 \%$ mortality $<1 y$ & $<5 y$ & SE & $\begin{array}{l}\text { male gender; age }<1 \mathrm{y} \text {; improved sanitation } \\
\text { coverage, expanding coverage of health services, } \\
\text { improving prenatal care and childhood and } \\
\text { increasing schooling. }\end{array}$ \\
\hline
\end{tabular}




\begin{tabular}{|c|c|c|c|c|c|c|}
\hline $\begin{array}{l}\text { Cesar et al. } \\
\text { (2009) [55] }\end{array}$ & $\begin{array}{l}\text { to evaluate child } \\
\text { health indicators in } \\
\text { two municipalities }\end{array}$ & $\begin{array}{l}\text { cross- } \\
\text { sectional }\end{array}$ & $\begin{array}{l}20 \% \text { had a height- } \\
\text { for-age deficit }>2 \\
\text { standard deviations }\end{array}$ & $<5 y$ & $\mathrm{~N}$ & $\begin{array}{l}60 \% \text { were from families with incomes } \\
\text { less than one monthly minimum wage } \\
\text { (approximately U } \$ 200 \text { ), } 41 \% \text { had no type } \\
\text { of sewage treatment or disposal, } 10 \% \text { of } \\
\text { mothers reported zero prenatal visits. }\end{array}$ \\
\hline $\begin{array}{l}\text { Genser et al. } \\
\text { (2008) [56] }\end{array}$ & $\begin{array}{l}\text { to investigate the } \\
\text { impact of a city- } \\
\text { wide sanitation } \\
\text { intervention in a } \\
\text { large urban center } \\
\text { in Northeast Brazil } \\
\text { on determinants of } \\
\text { child diarrhea }\end{array}$ & longitudinal & $\begin{array}{c}<\text { morbidity due to } \\
\text { diarrhea }\end{array}$ & $0-2$ y & $\mathrm{NE}$ & $\begin{array}{c}\text { poor socioeconomic status; the prevalence of } \\
\text { diarrhea decreased from } 9.2 \text { to } 7.3 \text { diarrhea } \\
\text { days per year after the intervention; a } \\
\text { reduction of } 21 \% . .\end{array}$ \\
\hline $\begin{array}{l}\text { Melo et al. } \\
(2008)[57]\end{array}$ & $\begin{array}{l}\text { to determine } \\
\text { the incidence } \\
\text { of diarrhea and } \\
\text { to assess some } \\
\text { relevant associated } \\
\text { factors to it in } \\
\text { children living in } \\
\text { two slums }\end{array}$ & longitudinal & $\begin{array}{l}\text { each child:11.1 days } \\
\text { of diarrhea per year }\end{array}$ & $<40 \mathrm{~m}$ & $\mathrm{NE}$ & $\begin{array}{c}\text { male gender, age }<1 \mathrm{y} \text {; early weaning; } \\
\text { mother younger than } 25 \text { years; malnourished, } \\
\text { missed immunizations and previous } \\
\text { pneumonia. }\end{array}$ \\
\hline $\begin{array}{l}\text { Vasconcelos } \\
\text { MJ; Batista F: } \\
\text { (2008) [58] }\end{array}$ & $\begin{array}{l}\text { to comparatively } \\
\text { assess the prevalence } \\
\text { of diarrhea and } \\
\text { the implications } \\
\text { of the disease } \\
\text { regarding outpatient } \\
\text { appointments and } \\
\text { hospitalizations }\end{array}$ & $\begin{array}{c}\text { cross- } \\
\text { sectional }\end{array}$ & $4.1 \%$ hospitalization & $<5 y$ & $\mathrm{NE}$ & $\begin{array}{l}\text { poor conditions of collective life in geographical } \\
\text { areas; diarrhea accounted for a quarter of all } \\
\text { admissions with a ratio of almost } 33 \% \text { in the urban } \\
\text { inland and } 35.3 \% \text { in the rural inland. }\end{array}$ \\
\hline $\begin{array}{l}\text { Barreto et al. } \\
\text { (2007) [59] }\end{array}$ & $\begin{array}{l}\text { to investigate the } \\
\text { epidemiological effect } \\
\text { of this city-wide } \\
\text { sanitation programme } \\
\text { on diarrhea morbidity } \\
\text { in children }\end{array}$ & longitudinal & $\begin{array}{c}22 \%<\text { morbdiity due to } \\
\text { diarrhea }\end{array}$ & $<36 \mathrm{~m}$ & $\mathrm{NE}$ & $\begin{array}{l}\text { diarrhea prevalence fell from } 9 \cdot 2 \text { days per child- } \\
\text { year before the citywide sanitation intervention to } \\
7 \cdot 3 \text { days per child-year afterwards. }\end{array}$ \\
\hline $\begin{array}{c}\text { Teixeira \& } \\
\text { Heller, }(2005) \\
{[60]}\end{array}$ & $\begin{array}{l}\text { to determine diarrhea } \\
\text { prevalence and } \\
\text { to identify factors } \\
\text { associated to the } \\
\text { condition in children } \\
\text { living in subnormal } \\
\text { settlement areas }\end{array}$ & $\begin{array}{c}\text { cross- } \\
\text { sectional }\end{array}$ & $17.5 \%$ diarrhea & $1-5 y$ & SE & $\begin{array}{l}\text { mine water consumption; sewage disposal on the } \\
\text { streets or in the yard; inadequate garbage disposal } \\
\text { and flies; child hospitalization during the first } \\
\text { month of life. }\end{array}$ \\
\hline $\begin{array}{l}\text { Zago-Gomes et } \\
\text { al. (2005) [61] }\end{array}$ & $\begin{array}{l}\text { to describe specific } \\
\text { anti-HAV prevalence } \\
\text { among school children }\end{array}$ & $\begin{array}{l}\text { cross- } \\
\text { sectional }\end{array}$ & $38.6 \%$ seropositive & $6-14 y$ & SE & $\begin{array}{c}\text { male=female gender; age }<10 \mathrm{y} \text {; absence of } \\
\text { domestic water filter, absence of sewage system and } \\
\text { a past history of hepatitis. }\end{array}$ \\
\hline $\begin{array}{c}\text { Teixeira JC; } \\
\text { Heller l. (2004) } \\
\text { [62] }\end{array}$ & $\begin{array}{l}\text { to identify the } \\
\text { environmental factors } \\
\text { related in children } \\
\text { living in areas } \\
\text { occupied by homeless } \\
\text { or landless people }\end{array}$ & $\begin{array}{l}\text { cross- } \\
\text { sectional }\end{array}$ & $\begin{array}{l}11.23 \% \text { chronic } \\
\text { malnutrition }\end{array}$ & $1-5 y$ & $\mathrm{SE}$ & $\begin{array}{l}\text { intermittent water supply, poor quality child } \\
\text { hygiene before feeding, and dumping children's } \\
\text { diapers with feces in the area around the house. }\end{array}$ \\
\hline $\begin{array}{l}\text { Vanderlei et al. } \\
\text { (2003) [63] }\end{array}$ & $\begin{array}{l}\text { to investigate the } \\
\text { socioeconomic, } \\
\text { demographic, } \\
\text { and biological } \\
\text { determinants of } \\
\text { hospitalization due to } \\
\text { acute diarrhea (AD) in } \\
\text { children }\end{array}$ & longitudinal & $100 \%$ hospitalization & $<2 y$ & $\mathrm{NE}$ & $\begin{array}{l}\text { age < six months; unfavorable socioeconomic } \\
\text { conditions, greater multiparity, younger age of the } \\
\text { child, and severity of the diarrhea. }\end{array}$ \\
\hline
\end{tabular}




\begin{tabular}{|c|c|c|c|c|c|c|}
\hline $\begin{array}{l}\text { Strina et al. } \\
\text { (2003) [64] }\end{array}$ & $\begin{array}{l}\text { to study the } \\
\text { determinants of } \\
\text { hygiene behavior } \\
\text { and of its role in } \\
\text { the transmission } \\
\text { or prevention of } \\
\text { diarrheal disease }\end{array}$ & longitudinal & $2.2 \%$ diarrheal disease & $<5 \mathrm{y}$ & $\mathrm{NE}$ & $\begin{array}{l}\text { the prevalence of diarrhea among children for } \\
\text { whom mainly unhygienic behavior and households } \\
\text { with inadequate excreta disposal was } 1.9 \text { times that } \\
\text { among children in the "mainly hygienic" group. }\end{array}$ \\
\hline $\begin{array}{l}\text { Schnack et al. } \\
\text { (2003) [65] }\end{array}$ & $\begin{array}{l}\text { to study the etiology } \\
\text { of childhood diarrhea } \\
\text { in a population sample } \\
\text { in a metropolitan area }\end{array}$ & longitudinal & $95.7 \%$ of diarrhea & $<5 \mathrm{y}$ & $\mathrm{S}$ & $\begin{array}{c}\text { Cryptosporidium (85.1\%), Entamoeba histolytica } \\
(56.4 \%) \text {, Giardia lamblia (4.3\%); environmental } \\
\text { conditions. }\end{array}$ \\
\hline $\begin{array}{l}\text { Medronho et al. } \\
\text { (2003) [66] }\end{array}$ & $\begin{array}{l}\text { to estimated risk } \\
\text { areas for hepatitis A } \\
\text { in four census tracts } \\
\text { in children living in a } \\
\text { metropolitan area }\end{array}$ & longitudinal & $33,3 \%$ seropositive & $1-9 y$ & SE & $\begin{array}{l}\text { area with poor environmental and sanitary } \\
\text { conditions. }\end{array}$ \\
\hline $\begin{array}{l}\text { Assis et al. } \\
(2002)[67]\end{array}$ & $\begin{array}{c}\text { to assess the } \\
\text { prevalence of } \\
\text { antibodies to hepatitis } \\
\mathrm{A} \text { and } \mathrm{E} \text { viruses in } \\
\text { children who were } \\
\text { students of nurseries } \\
\text { and public schools }\end{array}$ & $\begin{array}{c}\text { cross- } \\
\text { sectional }\end{array}$ & $\begin{array}{l}86,4 \% \text { anti-HAV/ } \\
4,5 \% \text { anti-HEV } \\
\text { seroprevalence }\end{array}$ & $2-9 y$ & $\mathrm{~N}$ & $\begin{array}{c}\text { male=female gender; low socioeconomic status and } \\
\text { poor sanitary hygienic. }\end{array}$ \\
\hline $\begin{array}{l}\text { Benicio \& } \\
\text { Monteiro, } \\
(2000)[68]\end{array}$ & $\begin{array}{l}\text { to characterize and } \\
\text { analyze trends of } \\
\text { children with diarrhea } \\
\text { using two household } \\
\text { surveys undertaken in } \\
\text { mid-80s and mid-90s. }\end{array}$ & $\begin{array}{c}\text { cross- } \\
\text { sectional }\end{array}$ & $\begin{array}{l}1.70 \% \text { to } 0.9 \% \\
\text { morbidity }\end{array}$ & $<5 y$ & SE & $\begin{array}{l}\text { age: } 6 \text { to } 23 \mathrm{~m} \text {; reduction in both the prevalence of } \\
\text { diarrhea and the hospitalizations due to the disease. } \\
\text { A more significant reduction was observed among } \\
\text { the third poorest families. }\end{array}$ \\
\hline $\begin{array}{c}\text { Catapreta \& } \\
\text { Heller, (1999) } \\
\text { [69] }\end{array}$ & $\begin{array}{l}\text { to describe the effects } \\
\text { of inadequate solid } \\
\text { waste collection } \\
\text { on the health in a } \\
\text { sample of children } \\
\text { living in low-income } \\
\text { neighborhoods and } \\
\text { favelas }\end{array}$ & $\begin{array}{c}\text { cross- } \\
\text { sectional }\end{array}$ & $\begin{array}{l}\text { diarrheal, parasitic, and } \\
\text { dermatological diseases }\end{array}$ & $<5 \mathrm{Y}$ & SE & age: 6 to $23 \mathrm{~m}$; absence of solid waste collection. \\
\hline
\end{tabular}

Even though diarrheal diseases represent the second most common cause for hospital admissions in children under 5 years of age [48], researches have seen a considerable decrease in morbimortality caused by those illnesses. The factors that may have contributed to that decrease were the increase in purchasing power and consequently the betterment of living conditions [54] and the increase in the coverage of basic sanitation services [56, 59].

Author's suggested that hepatitis A, another disease related to water-transmitted illnesses, is also present in area with poor environmental and sanitary conditions. The prevalence of positive anti-HAV among school children was significantly associated with low socioeconomic status $[51,66,67]$, absence of both domestic water filter and sewage system [61] and indoor crowding [52].

Still in the Social research block, in the "prevalence of intestinal parasites", 27 articles were used (Tab. IV). The studies suggest that geo-helminths represent a major public health problem and are an important indicator of the sanitary conditions in which a certain population lives. The association between the prevalence of intestinal parasitic diseases with socioeconomic and environmental factors was reported in the most of researches like: children from slums [71] or residing in townships with a low HDI in the $\mathrm{N}$ and NE regions, especially in rural areas
[74]; households with no proper waste management and no solid residue collection [78]; the unhealthy condition to which this population is subjected $[72,87]$, with a direct relationship with low maternal schooling [81, 95] and low income family [80, 85-91, 95]. The higher prevalence of Ascaris lumbricoides, Giardia duodenalis, Trichuris trichiura and hookworm infections in children living in contaminated environments [75, 90, 92, 93] with inadequate daily caloric intake [94] may result in hospitalizations due to diarrheal disease [79], compromising their future anthropometric status [76, 94].

On the other hand, studies suggested that a reduction of the prevalence of the parasites infections was possible by the increase of sewage systems $[73,88,89,91,92]$, the use of a water filter [70] and the household being in an urban area [96].

The prevalence of parasitic diseases in children who go to daycare was another topic in this research. Daycares were found to contain giardiasis $[82,83,95]$ and several helminths $[77,84$, 86]. The variable 'drinking water' showed a great influence on endoparasitic diseases in children of public institutions that ingested water without in-home treatment [81, 95]. Another variable, the relationship between the presence of helminth eggs in the water closet of kinder garden and the frequency of these eggs in the feces of their users were $15,4 \%$ positive. 

Threats

\section{Table IV: SOCIAL - SANITATION AND SOCIO-ENVIRONMENTAL FACTORS}

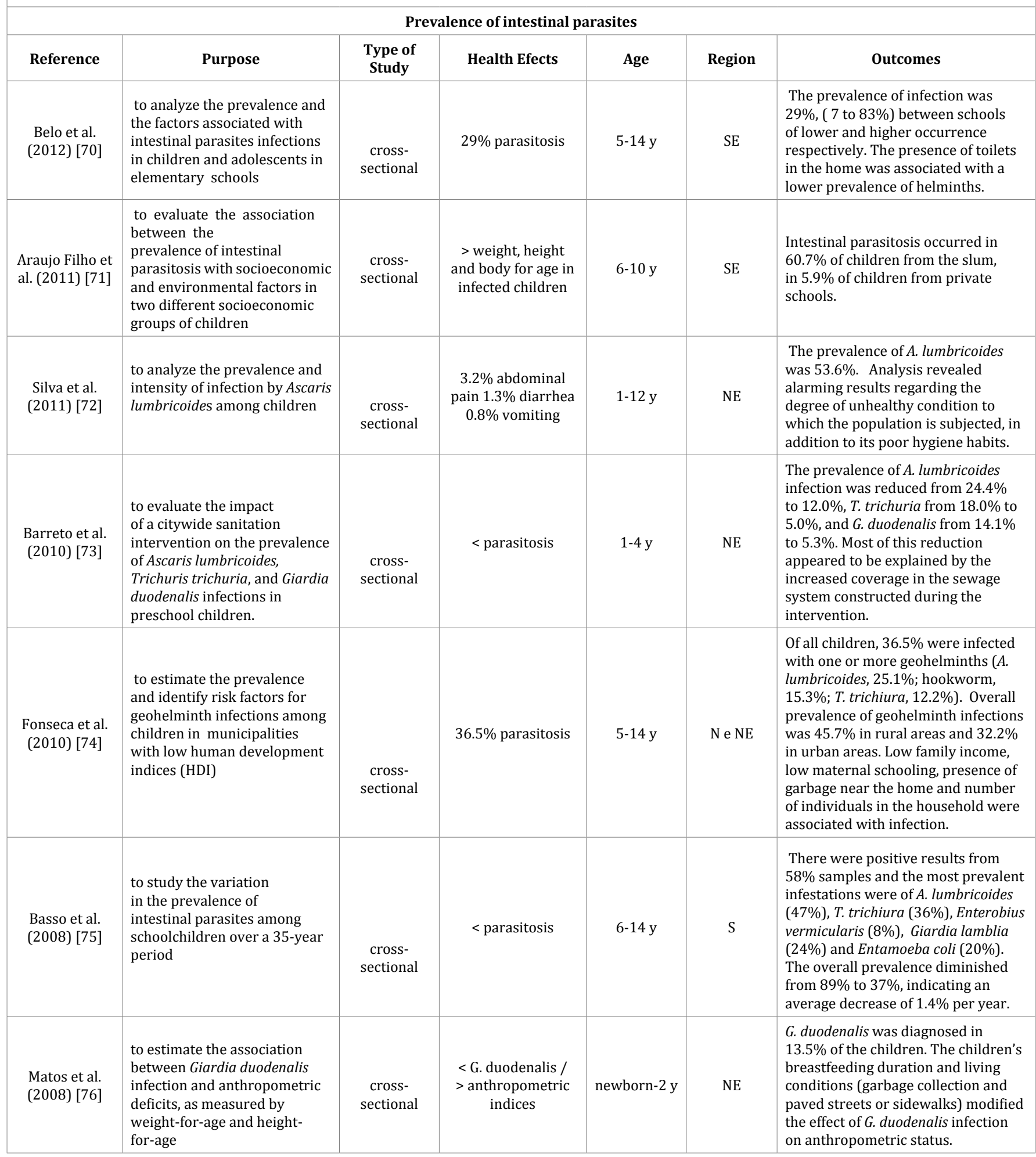




\begin{tabular}{|c|c|c|c|c|c|c|}
\hline $\begin{array}{l}\text { Araújo et al. } \\
\text { (2008) [77] }\end{array}$ & $\begin{array}{l}\text { to test for helminthes in } \\
\text { sandboxes public and private } \\
\text { in day care centers }\end{array}$ & $\begin{array}{c}\text { cross- } \\
\text { sectional }\end{array}$ & $60 \%$ helminthiasis & $4-6 y$ & SE & $\begin{array}{l}\text { In the private day care centers, } 61 \% \\
\text { were positive for helminthes larvae } \\
\text { and } 50 \% \text { for eggs. In the public day } \\
\text { care centers, } 64 \% \text { were positive } \\
\text { for larvae and } 36 \% \text { for eggs. No } \\
\text { influence of either season of the year } \\
\text { or day care finance condition was } \\
\text { seen. }\end{array}$ \\
\hline $\begin{array}{l}\text { Moraes et al. } \\
\text { (2007) [78] }\end{array}$ & $\begin{array}{l}\text { to study the bagging and } \\
\text { collection of household } \\
\text { solid waste and the health } \\
\text { implications for children living } \\
\text { in human settlements }\end{array}$ & $\begin{array}{c}\text { cross- } \\
\text { sectional }\end{array}$ & $\begin{array}{l}\text { more than } 5 \\
\text { episodes of } \\
\text { diarrhea per year }\end{array}$ & $5-14 y$ & $\mathrm{NE}$ & $\begin{array}{l}\text { There was a higher prevalence of } \\
\text { A. lumbricoides, T. trichiura and } \\
\text { hookworm in children living in } \\
\text { households without proper bagging/ } \\
\text { isolation and collection of household } \\
\text { solid waste as compared to those in } \\
\text { areas with regular garbage collection } \\
\text { and adequate isolation of solid waste. }\end{array}$ \\
\hline $\begin{array}{l}\text { Pereira et al. } \\
\text { (2007) [79] }\end{array}$ & $\begin{array}{l}\text { to determine the prevalence } \\
\text { and to identify risk factors } \\
\text { associated with Giardia } \\
\text { lamblia infection in diarrheic } \\
\text { children hospitalized for } \\
\text { diarrhea }\end{array}$ & $\begin{array}{c}\text { cross- } \\
\text { sectional }\end{array}$ & $\begin{array}{c}9.9 \% \\
\text { hospitalization }\end{array}$ & $\begin{array}{c}\text { newborn } \\
-10 y\end{array}$ & CO & $\begin{array}{l}\text { Associated factors: age of children } \\
\text { ( } 24-48 \text { months); predisponding } \\
\text { factors: number of children and cats } \\
\text { in the household, food hygiene, day- } \\
\text { care centers attendance, living on a } \\
\text { rural farm within the past six months } \\
\text { prior hospitalization and the number } \\
\text { of household adults. }\end{array}$ \\
\hline $\begin{array}{l}\text { Buschini et al. } \\
\text { (2007) [80] }\end{array}$ & $\begin{array}{l}\text { to analyze the distribution and } \\
\text { frequency of enteroparasite } \\
\text { occurrence in children from } \\
\text { seven community schools }\end{array}$ & $\begin{array}{c}\text { cross- } \\
\text { sectional }\end{array}$ & $\begin{array}{l}\text { highly infected by } \\
\text { enteroparasites }\end{array}$ & $\begin{array}{c}\text { newborn } \\
-15 y\end{array}$ & $S$ & $\begin{array}{l}\text { They found that } 75.27 \% \text { of children } \\
\text { had enteroparasites. A smaller } \\
\text { fraction }(26.73 \%) \text { of children } \\
\text { harbored several parasites } \\
\text { (multiparasitism), especially } \\
\text { G. duodenalis (56\%), and } A \text {. } \\
\text { lumbricoides (18\%). }\end{array}$ \\
\hline $\begin{array}{l}\text { Mascarini } \\
\text { \& Donalísio } \\
\text { (2006a) [81] }\end{array}$ & $\begin{array}{l}\text { to estimate the prevalence } \\
\text { and incidence of intestinal } \\
\text { parasites among children at } \\
\text { municipal daycare centers }\end{array}$ & longitudinal & $23.2 \%$ positive & $\begin{array}{c}\text { newborn } \\
-6 y\end{array}$ & SE & $\begin{array}{l}\text { The enteroparasite prevalence } \\
\text { was } 76.74 \% \text { in } 2002 \text { and } 34 \% \text { in } \\
2003 \text {. Associated factors to a higher } \\
\text { prevalence of enteroparasitosis: } \\
\text { gender male and } 72-83 \text { month age } \\
\text { group children ( } 84.37 \%) \text {. Greater } \\
\text { prevalence in enteroparasitosis } \\
\text { acquisition in the children that } \\
\text { ingested water without in-home } \\
\text { treatment. }\end{array}$ \\
\hline $\begin{array}{c}\text { Mascarini } \\
\text { \& Donalísio } \\
\text { (2006b) [82] }\end{array}$ & $\begin{array}{l}\text { to estimate the prevalence } \\
\text { of intestinal parasites among } \\
\text { children at municipal daycare } \\
\text { centers }\end{array}$ & $\begin{array}{c}\text { cross- } \\
\text { sectional }\end{array}$ & $22.5 \%$ G. duodenalis & $0-6 y$ & SE & $\begin{array}{l}\text { G. duodenalis presented prevalence } \\
\text { of } 23.7 \%(2002) \text { and } 21.4 \% \text { (2003) } \\
\text { followed by Cryptosporidium sp. } \\
\text { with } 15.5 \%(2002) \text { and } 3.7 \% \text { (2003) } \\
\text { and Blastocystis hominiswith } 13.1 \% \\
\text { (2002) and 5.5\% (2003). }\end{array}$ \\
\hline $\begin{array}{c}\text { Carvalho et al. } \\
\text { (2006) [83] }\end{array}$ & $\begin{array}{l}\text { to investigate possible } \\
\text { associations between } \\
\text { occurrence of enteroparasites } \\
\text { and the socioeconomic and } \\
\text { sanitary conditions of children } \\
\text { matriculated in day care } \\
\text { centers }\end{array}$ & $\begin{array}{c}\text { cross- } \\
\text { sectional }\end{array}$ & $53.4 \%$ positive & $\begin{array}{c}\text { newborn } \\
-6 y\end{array}$ & SE & $\begin{array}{l}\text { Associated factors: G. duodenalis } \\
\text { was more prevalent in children from } \\
0 \text { to } 4 \text { years and E. vermicularis in } \\
\text { children between three and four } \\
\text { years old. The prevalence of intestinal } \\
\text { parasitism was } 53.40 \% \text {, and the most } \\
\text { frequent parasite was G. duodenalis } \\
(26.88 \%) \text {. Predisposing factors: } \\
\text { family income, maternal education } \\
\text { and factors beyond sanitation should } \\
\text { be considered. }\end{array}$ \\
\hline $\begin{array}{l}\text { Gurgel et al. } \\
(2005) \text { [84] }\end{array}$ & $\begin{array}{l}\text { to evaluate whether child } \\
\text { daycare centers are an } \\
\text { environment that protects } \\
\text { against or exposes children to } \\
\text { intestinal parasite infestation. }\end{array}$ & longitudinal & $63 \%$ positive & $1-5 \mathrm{y}$ & $\mathrm{NE}$ & $\begin{array}{l}\text { The overall prevalence was } 51 \% \text { of at } \\
\text { least } 1 \text { parasite. There was a higher } \\
\text { prevalence of intestinal parasites } \\
(63 \%) \text { in children who attended day } \\
\text { care than those who did not attend } \\
(41.4 \%) \text { and the risk of infestation is } \\
1.5 \text { times higher. }\end{array}$ \\
\hline
\end{tabular}




\begin{tabular}{|c|c|c|c|c|c|c|}
\hline $\begin{array}{c}\text { Teixeira \& } \\
\text { Heller (2004) } \\
\text { [85] }\end{array}$ & $\begin{array}{l}\text { to characterize the } \\
\text { morbidity by intestinal } \\
\text { helminth infections and } \\
\text { the identification of the } \\
\text { factors associated with these } \\
\text { diseases, with emphasis on } \\
\text { environmental factors, in } \\
\text { children residing in subnormal } \\
\text { settlement areas }\end{array}$ & $\begin{array}{l}\text { cross- } \\
\text { sectional }\end{array}$ & $21.3 \%$ positive & $1-5 y$ & SE & $\begin{array}{l}21.38 \% \text { of sample children presented } \\
\text { intestinal helminth infections. The } \\
\text { associated and predisponding factors } \\
\text { with these parasitic diseases included } \\
\text { the children's age, family income, } \\
\text { complaints about the quality of the } \\
\text { water from the public system and } \\
\text { deficiencies in sanitation. }\end{array}$ \\
\hline $\begin{array}{l}\text { Quadros et al. } \\
\text { (2004) [86] }\end{array}$ & $\begin{array}{l}\text { to determine the prevalence } \\
\text { and intensity of infection by } \\
\text { intestinal parasites among } \\
\text { children attending early } \\
\text { education centers }\end{array}$ & $\begin{array}{l}\text { cross- } \\
\text { sectional }\end{array}$ & $70 \%$ positive & $2-6 y$ & $\mathrm{~S}$ & $\begin{array}{l}\text { Associated factors: gender female. } \\
\text { The overall prevalence of helminths } \\
\text { and protozoa was } 70.5 \% \text { - A. } \\
\text { lumbricoides (35\%), G. lamblia (14\%) } \\
\text { and T. trichiura (13\%) among other } \\
\text { parasites. }\end{array}$ \\
\hline $\begin{array}{l}\text { Ferreira et al. } \\
(2003)[87]\end{array}$ & $\begin{array}{l}\text { to verify the occurrence } \\
\text { of intestinal parasites and } \\
\text { commensal organisms among } \\
\text { children attending a school } \\
\text { located in a settlement of } \\
\text { 'landless farm workers' }\end{array}$ & $\begin{array}{l}\text { cross- } \\
\text { sectional }\end{array}$ & $59.7 \%$ positive & $5-14$ y & SE & $\begin{array}{l}59.7 \% \text { of intestinal parasites and } \\
\text { commensals occurred in the study } \\
\text { population - G. lamblia in } 30.5 \% \\
\text { of fecal samples and Schistosoma } \\
\text { mansoni in only } 1 \text { case. }\end{array}$ \\
\hline $\begin{array}{l}\text { Carneiro et al. } \\
\text { (2002) [88] }\end{array}$ & $\begin{array}{l}\text { to develop an environmental } \\
\text { health indicator for use } \\
\text { as a basis for developing } \\
\text { preventive measures against } \\
\text { Ascaris lumbricoides infection } \\
\text { in children }\end{array}$ & $\begin{array}{l}\text { cross- } \\
\text { sectional }\end{array}$ & $\begin{array}{l}\text { 12.2\% positive } \\
\text { A. lumbricoides } \\
\text { infection }\end{array}$ & $0-14$ y & SE & $\begin{array}{l}\text { The results showed the protective } \\
\text { effects of availability of water in } \\
\text { the washbasin, better hygiene, } \\
\text { sanitation and socioeconomic status; } \\
\text { the interactive effect of crowding } \\
\text { was five times larger in households } \\
\text { without water in the washbasin than } \\
\text { in those having water. }\end{array}$ \\
\hline $\begin{array}{c}\text { Carvalho et al. } \\
\text { (2002) [89] }\end{array}$ & $\begin{array}{l}\text { to analyze the prevalence of } \\
\text { intestinal helminth infections } \\
\text { in mesoregions considered } \\
\text { harmless for schistosomiasis }\end{array}$ & $\begin{array}{l}\text { cross- } \\
\text { sectional }\end{array}$ & $18 \%$ positive & $7-14 y$ & SE & $\begin{array}{l}\text { The largest helminthes prevalence/ } \\
\text { mesoregion was for T. trichiura } \\
(24.2 \%) \text { and A. lumbricoides (18.7\%) } \\
\text { in the south/south-west region; } \\
\text { hookworm (12.1\%) and Taenia sp. } \\
(0.7 \%) \text { in the northwest region of the } \\
\text { study area. }\end{array}$ \\
\hline $\begin{array}{l}\text { Prado et al. } \\
\text { (2001) [90] }\end{array}$ & $\begin{array}{l}\text { to study the prevalence } \\
\text { and intensity of infection by } \\
\text { intestinal parasites in a sample } \\
\text { of school children }\end{array}$ & $\begin{array}{l}\text { cross- } \\
\text { sectional }\end{array}$ & $66.1 \%$ positive & $7-14$ y & $\mathrm{NE}$ & $\begin{array}{l}\text { The most frequent intestinal } \\
\text { parasites: } \text { T. trichiura }(38.6 \%), A . \\
\text { lumbricoides }(31.2 \%) \text {, hookworms } \\
\text { ( } 8.4 \%) \text {, Schistosoma mansoni }(2.2 \%) \text {, } \\
\text { G. lamblia }(8.9 \%) \text { and Entamoeba } \\
\text { histolytica }(5.5 \%) .\end{array}$ \\
\hline $\begin{array}{l}\text { Ferreira et al. } \\
(2000) \text { [91] }\end{array}$ & $\begin{array}{l}\text { to characterize and analyse } \\
\text { trends in infant and child } \\
\text { intestinal parasitic diseases } \\
\text { using two household surveys } \\
\text { undertaken in mid-80s and } \\
\text { mid-90s }\end{array}$ & $\begin{array}{l}\text { cross- } \\
\text { sectional }\end{array}$ & $\begin{array}{c}<\text { parasitosis from } \\
30.9 \% \text { to } 10.7 \%\end{array}$ & $<5 y$ & SE & $\begin{array}{l}\text { Helminthes in general (from } 22.3 \% \\
\text { to } 4.8 \% \text { ) and giardiasis (from } 14.5 \% \\
\text { to } 5.5 \% \text { ). A significant decline in } \\
\text { prevalence was observed in all social } \\
\text { strata and the inverse association } \\
\text { between income and intestinal } \\
\text { parasites was kept unchanged in the } \\
\text { period. }\end{array}$ \\
\hline $\begin{array}{l}\text { Rocha et al. } \\
\text { (2000) [92] }\end{array}$ & $\begin{array}{l}\text { to determine the prevalence } \\
\text { of intestinal parasitosis } \\
\text { in a school children and } \\
\text { reevaluating the snails' } \\
\text { breeding places described in } \\
\text { the county }\end{array}$ & $\begin{array}{c}\text { cross- } \\
\text { sectional }\end{array}$ & $20.1 \%$ positive & $0-14 y$ & SE & $\begin{array}{l}20.1 \% \text { of children had at least one } \\
\text { parasitic infection; G. lamblia, E. coli, } \\
\text { A. lumbricoides and hookworm were } \\
\text { the most frequent parasites, with a } \\
\text { prevalence of } 6.2 \%, 6.2 \%, 4.8 \% \text { and } \\
1.4 \% \text {, respectively. The hookworms } \\
\text { were more frequent among students } \\
\text { from the rural area ; the prevalence } \\
\text { of E. coli was greater in the urban } \\
\text { area. }\end{array}$ \\
\hline
\end{tabular}




\begin{tabular}{|c|c|c|c|c|c|c|}
\hline $\begin{array}{c}\text { Tsuyuoka et al. } \\
\text { (1999) [93] }\end{array}$ & $\begin{array}{l}\text { to describe the prevalence of } \\
\text { anemia, parasitic infections, } \\
\text { and nutritional status of } \\
\text { children attending public } \\
\text { primary schools }\end{array}$ & $\begin{array}{l}\text { cross- } \\
\text { sectional }\end{array}$ & $\begin{array}{l}26.7 \% \text { anemia/ } \\
42 \% \text { parasitosis }\end{array}$ & $4-15 y$ & $\mathrm{NE}$ & $\begin{array}{l}\text { Overall prevalence of intestinal } \\
\text { parasites was } 42 \% \text {; } \text {. lumbricoides } \\
(28.7 \%), T \text {. trichiura }(15.6 \%) \text {, and } \\
\text { hookworm (1.7\%). There was } \\
\text { an association between parasitic } \\
\text { infections and poor sanitary } \\
\text { conditions, but there was no } \\
\text { association between anemia and } \\
\text { presence of intestinal parasites. }\end{array}$ \\
\hline $\begin{array}{l}\text { Saldiva et al. } \\
\text { (1999) [94] }\end{array}$ & $\begin{array}{l}\text { to evaluate the role of } \\
\text { intestinal parasites on } \\
\text { nutritional status in three } \\
\text { rural areas of Brazil }\end{array}$ & $\begin{array}{c}\text { cross- } \\
\text { sectional }\end{array}$ & $\begin{array}{l}78 \% \text { inadequate } \\
\text { daily caloric intake/ } \\
34 \% \text { inadequate } \\
\text { protein daily intake }\end{array}$ & $1-12 y$ & SE & $\begin{array}{l}\text { G. lamblia (44\%), Endolimax nana } \\
\text { (43\%), A. lumbricoides ( } 41 \%) \text { and } \\
\text { T. trichiura ( } 40 \% \text { ) were the most } \\
\text { prevalent; } 11 \% \text { of the children were } \\
\text { considered as showing stunting. }\end{array}$ \\
\hline $\begin{array}{l}\text { Machado et al. } \\
\text { (1999) [95] }\end{array}$ & $\begin{array}{l}\text { to show different frequencies } \\
\text { of intestinal parasitosis } \\
\text { (giardiasis and helminthiasis) } \\
\text { among children in day-care } \\
\text { centers and junior and high } \\
\text { schools (public and private) }\end{array}$ & $\begin{array}{l}\text { cross- } \\
\text { sectional }\end{array}$ & $\begin{array}{l}>\text { morbidity in } \\
\text { daycare centers }\end{array}$ & $2-15 y$ & SE & $\begin{array}{l}\text { The frequency of giardiasis in } \\
\text { public institutions was shown to be } \\
\text { greater than in private institutions. } \\
\text { Helminthiasi, frequencies were } \\
\text { similar among day-care centers, but } \\
\text { greater for public schools among } \\
\text { children from low-income families } \\
\text { and those whose parents had low } \\
\text { levels of education. }\end{array}$ \\
\hline $\begin{array}{l}\text { Coelho et al. } \\
\text { (1999) [96] }\end{array}$ & $\begin{array}{l}\text { to establish a relationship } \\
\text { between the presence of } \\
\text { helminth eggs in the water } \\
\text { closet elements and the } \\
\text { frequency of these eggs in the } \\
\text { feces of their users }\end{array}$ & $\begin{array}{l}\text { cross- } \\
\text { sectional }\end{array}$ & $\begin{array}{l}15.4 \% \text { of infected } \\
\text { children }\end{array}$ & $2-6 y$ & SE & $\begin{array}{l}\text { The contamination levels in } \\
\text { the children's feces was } 37.8 \% \\
\text { and } 16.1 \% \text { in the toilets. The } \\
\text { school which showed the lowest } \\
\text { contamination by intestinal } \\
\text { helminths }(12 \% \text { in feces and } 0 \% \text { in } \\
\text { the toilets) was the one that was } \\
\text { located in the most central area of } \\
\text { the city. There was not significant } \\
\text { relationship between the elements } \\
\text { of water closets and user's feces } \\
\text { contamination. }\end{array}$ \\
\hline
\end{tabular}

The researchers found in 23 infected elements eggs of Ascaris lumbricoides, Enterobius vermicularis and larvs of nemathoids partially deformed [96].

\section{Regional - Regional environmental factors}

In this segment, 56 articles were chosen and divided in three subthemes ranging from the "impacts of air pollution on respiratory diseases", "exposure to chemical micropollutants" and "exposure to other biological agents" on children's health.

For the first subtheme "impacts of air pollution on respiratory diseases", 28 articles were used (Tab. V). A significant association between risk of low birth weight and exposure to pollutants was found, like $\mathrm{PM}_{10}$, $\mathrm{CO}[98,112,118], \mathrm{SO}_{2}$ and $\mathrm{O}_{3}$ [107]. A research [108] also revealed a gradient of approximately $50 \%$ of increasing risk of early neonatal death with higher exposure to traffic-related air pollution, compared with those less exposed.

Several authors have explored the deleterious effect of outdoor air pollution on pediatric respiratory morbidity $[117,119,124]$ with decrease in lung function [106], with increased risk for asthma [111] and pneumonia in children $[99,113]$ in urban areas like the cities of São Paulo [100, 114, 122, 123], Rio de Janeiro [105], Curitiba [119] and Sobral [104]. Considering the lack of information on the air pollution effects on mortality in children's group, a study [121] showed the significant association between respiratory mortality in children and air pollution, in a city of SE Region. The estimated proportions of respiratory deaths attributed to $\mathrm{CO}, \mathrm{SO}_{2}$, and $\mathrm{PM}_{10}$, when considered individually, were around $15 \%, 13 \%$, and $7 \%$, respectively.

Authors also observed a higher prevalence of Respiratory Diseases (RD) associated with seasonality. In the SE region [102] the highest number of hospital admissions happened in the peak of the transition between Summer and Fall, in the N and CO regions the hospitalization of RD was seen both in the dry [109, $115]$ and in the wet season $[110,116,120]$.

Another point of focus for the study was a relation between exposure to fine particulate matter from fire and the prevalence of RD in children. Andrade Filho et al. [97] noted that respiratory diseases may be more associated to meteorological conditions, especially humidity, than to exposure to aerosols from fires in the $\mathrm{N}$ region. Riguera et al. [101], while studying pollution from burning sugarcane and respiratory symptoms in school age children in the SE region, noted a higher frequency of rhinitis in the harvesting period for sugarcane.

Another point of focus for the study was a relation between exposure to fine particulate matter from fire and the prevalence of RD in children. Andrade Filho et al. [97] noted that respiratory diseases may be more associated to meteorological conditions, especially humidity, than to exposure to aerosols from fires in the $\mathrm{N}$ region. Riguera et al. [101], while studying pollution from burning sugarcane and respiratory symptoms in school age children in the SE region, noted a higher frequency of rhinitis in the harvesting period for sugarcane. 


\begin{tabular}{|c|c|c|c|c|c|c|}
\hline \multicolumn{7}{|c|}{ Impacts of air pollution on respiratory diseases } \\
\hline Reference & Purpose & $\begin{array}{l}\text { Type of } \\
\text { Study }\end{array}$ & Health Efects & Age & Region & Outcomes \\
\hline $\begin{array}{l}\text { Andrade Filho et } \\
\text { al.(2013) [97] }\end{array}$ & $\begin{array}{l}\text { to investigate the effects } \\
\text { of fine particulate } \\
\text { matter emitted through } \\
\text { biomass burning on } \\
\text { hospitalizations for } \\
\text { respiratory diseases in } \\
\text { children living Northern } \\
\text { region }\end{array}$ & longitudinal & $45 \%$ pneumonia & $<9 y$ & $\mathrm{~N}$ & $\begin{array}{c}\text { male gender: age:<1 y } \\
(46,6 \%) ; 1-4 \text { y }(39,6 \%) ; \\
5-9 \text { y }(20,6 \%) ; \text { weather } \\
\text { conditions: dry season; } \\
\text { relative humidity than to } \\
\text { exposure to aerosols emitted } \\
\text { by biomass burning in the } \\
\text { Amazonian region. }\end{array}$ \\
\hline $\begin{array}{l}\text { Romão et al. } \\
\text { (2013) [98] }\end{array}$ & $\begin{array}{l}\text { to analyze the } \\
\text { relationship between } \\
\text { exposure to PM10 and } \\
\text { low birth weight in a } \\
\text { city in the southeast } \\
\text { region }\end{array}$ & longitudinal & $\begin{array}{c}5,9 \% \text { of low birth } \\
\text { weight }\end{array}$ & newborn & SE & $\begin{array}{l}\text { male gender; air pollution } \\
\text { influences pregnancy } \\
\text { outcomes; This effect was } \\
\text { dose-dependent and was } \\
\text { observed for all pregnancy } \\
\text { exposure windows }\end{array}$ \\
\hline $\begin{array}{l}\text { Vieira et al. } \\
\text { (2012) [99] }\end{array}$ & $\begin{array}{l}\text { to evaluate the role of } \\
\text { outdoor, indoor and } \\
\text { personal exposure to } \\
\text { combustion-related } \\
\text { pollutants } \mathrm{NO}_{2} \text { and } \mathrm{O}_{3} \\
\text { on respiratory health of } \\
\text { children }\end{array}$ & longitudinal & $67.2 \%$ wheezing & $6-10 y$ & SE & $\begin{array}{c}\text { male gender; age:8,5 y } \\
\text { (media); exposure to } \\
\text { higher levels of } \mathrm{NO}_{2} \text { and } \\
\mathrm{O}_{3} \text { was associated with } \\
\text { increased risk for asthma } \\
\text { and pneumonia in children. } \\
\text { The measurements taken } \\
\text { in indoor and personal } \\
\text { exposure were the most } \\
\text { accurate. }\end{array}$ \\
\hline $\begin{array}{l}\text { Jasinski et al. } \\
\text { (2011) [100] }\end{array}$ & $\begin{array}{l}\text { to evaluate the effects of } \\
\text { air pollutants in relation } \\
\text { to respiratory morbidity } \\
\text { among children and } \\
\text { adolescents }\end{array}$ & longitudinal & $\begin{array}{c}\text { > respiratory } \\
\text { hospital } \\
\text { admissions }\end{array}$ & $<19 y$ & SE & $\begin{array}{c}\text { aged: }<5 \text { y }(85,6 \%) ; 9,6 \% \\
\text { higher of } \mathrm{PM}_{10} \text { and } 2,4 \% \\
\text { higher of } \mathrm{O}_{3} \text { increased } \\
\text { adverse effects on children } \\
\text { and adolescents pulmonary } \\
\text { function. }\end{array}$ \\
\hline $\begin{array}{l}\text { Riguera et al. } \\
\text { (2011) [101] }\end{array}$ & $\begin{array}{l}\text { to estimate the } \\
\text { prevalence of } \\
\text { respiratory symptoms } \\
\text { and to analyze } \\
\text { associated factors as } \\
\text { well as peak expiratory } \\
\text { flow measurements in } \\
\text { schoolchildren }\end{array}$ & $\begin{array}{l}\text { cross- } \\
\text { sectional }\end{array}$ & $\begin{array}{l}11 \% \text { asthma } \\
33,2 \% \text { rhinitis }\end{array}$ & $10-14 y$ & SE & $\begin{array}{l}\text { male gender; age: }<13 \\
\text { y; } 94.5 \% \text { lived in the } \\
\text { urban zone ; greater } \mathrm{PM}_{2,5} \\
\text { concentration; rhinitis - from } \\
\text { June to October, a period } \\
\text { that matches the sugarcane } \\
\text { harvest season; pollution in } \\
\text { the cane trash burn season } \\
\text { may contribute to the } \\
\text { exacerbation of asthma and } \\
\text { rhinitis episodes }\end{array}$ \\
\hline $\begin{array}{l}\text { Natali et al. } \\
\text { (2011) [102] }\end{array}$ & $\begin{array}{l}\text { to analyze the profile } \\
\text { of children and } \\
\text { adolescents' hospital } \\
\text { admissions due to } \\
\text { respiratory diseases in } \\
\text { a city in the southeast } \\
\text { region }\end{array}$ & longitudinal & $\begin{array}{l}51 \% \text { pneumonia/ } \\
18 \% \text { asthma }\end{array}$ & $<19 y$ & SE & $\begin{array}{l}\text { male gender; age under } \\
5 \mathrm{y} \text {; there is an obvious } \\
\text { seasonality to admissions } \\
\text { with the most significant } \\
\text { peaks occurring in early } \\
\text { autumn. }\end{array}$ \\
\hline $\begin{array}{l}\text { Moraes et al. } \\
(2010) \text { [103] }\end{array}$ & $\begin{array}{l}\text { to examine the } \\
\text { association between } \\
\text { wheezing in children } \\
\text { and adolescents and } \\
\text { living downwind of the } \\
\text { dispersion plume of } \\
\text { atmospheric pollutants } \\
\text { emitted by the Guamaré } \\
\text { Petrochemical Complex }\end{array}$ & $\begin{array}{l}\text { cross- } \\
\text { sectional }\end{array}$ & $27,3 \%$ wheezing & $<-14$ y & NE & $\begin{array}{l}\text { male gender; age }<5 \text { y; } \\
\text { respiratory symptoms in } \\
\text { children and adolescents } \\
\text { were associated with } \\
\text { living downwind of a } \\
\text { petrochemical plant. }\end{array}$ \\
\hline
\end{tabular}




\begin{tabular}{|c|c|c|c|c|c|c|}
\hline $\begin{array}{c}\text { Barreto \& } \\
\text { Grisi , (2010) [104] }\end{array}$ & $\begin{array}{l}\text { to assess self-reported } \\
\text { morbidity among } \\
\text { children and to analyze } \\
\text { its conditioning factors }\end{array}$ & $\begin{array}{l}\text { cross- } \\
\text { sectional }\end{array}$ & $\begin{array}{c}28,7 \% \text { respiratory } \\
\text { diseases }\end{array}$ & $5-9 y$ & $\mathrm{NE}$ & $\begin{array}{l}\text { male=female gender; low- } \\
\text { income population; highest } \\
\text { rates of respiratory diseases } \\
\text { were seen in April, May } \\
\text { and June - the rainy months } \\
\text {; finding is suggestive } \\
\text { either of over reporting or } \\
\text { environmental pollution. }\end{array}$ \\
\hline $\begin{array}{l}\text { Moura et al. } \\
\text { (2009) [105] }\end{array}$ & $\begin{array}{l}\text { to estimate the } \\
\text { association between } \\
\text { levels of air pollutants } \\
\text { and respiratory } \\
\text { symptoms in children }\end{array}$ & longitudinal & $\begin{array}{c}\text { 6,7\% morbidity } \\
\mathrm{PM}_{10} \\
\text { 3\% morbidity } \mathrm{O}_{3}\end{array}$ & $1 \mathrm{~m}-12 \mathrm{y}$ & SE & $\begin{array}{c}\text { age: }<2 \mathrm{y} \text {; exposure to air } \\
\text { pollutants was associated } \\
\text { with a significant increase } \\
\text { in emergency paediatric } \\
\text { visits due to symptoms of } \\
\text { bronchial obstruction in } \\
\text { children.. }\end{array}$ \\
\hline $\begin{array}{l}\text { Castro et al. } \\
(2009)[106]\end{array}$ & $\begin{array}{l}\text { to assess the association } \\
\text { between daily exposure } \\
\text { to air pollution and } \\
\text { lung function in school } \\
\text { children }\end{array}$ & $\begin{array}{l}\text { cross- } \\
\text { sectional }\end{array}$ & $\begin{array}{l}\text { decrease in lung } \\
\text { function }\end{array}$ & $6-14 y$ & SE & $\begin{array}{l}\text { male=female gender; air } \\
\text { pollution, especially } \mathrm{PM}_{10} \\
\text { and } \mathrm{NO}_{2} .\end{array}$ \\
\hline $\begin{array}{c}\text { Nascimento \& } \\
\text { Moreira, (2009) } \\
{[107]}\end{array}$ & $\begin{array}{l}\text { to assess the association } \\
\text { between prenatal } \\
\text { exposure to air } \\
\text { pollutants and low birth } \\
\text { weight in a medium- } \\
\text { sized city }\end{array}$ & longitudinal & $\begin{array}{c}\text { 3.95\% low birth } \\
\text { weight }\end{array}$ & newborn & SE & $\begin{array}{l}\text { the pollutants } \mathrm{SO}_{2} \text { and } \mathrm{O}_{3} \\
\text { were associated with low } \\
\text { birth weight. }\end{array}$ \\
\hline $\begin{array}{l}\text { Medeiros et al. } \\
(2009)[108]\end{array}$ & $\begin{array}{l}\text { to examine the } \\
\text { association between } \\
\text { traffic-related pollution } \\
\text { and peri- natal mortality }\end{array}$ & longitudinal & $>$ neonatal death & newborn & SE & $\begin{array}{l}\text { mothers exposed to } \\
\text { the highest quartile of } \\
\text { the distance-weighted } \\
\text { traffic density, exhibited } \\
\text { approximately } 50 \% \\
\text { increased risk compared } \\
\text { with those less exposed }\end{array}$ \\
\hline $\begin{array}{c}\text { Rosa et al. } \\
\text { (2008a) [109] }\end{array}$ & $\begin{array}{l}\text { to analyze } \\
\text { hospitalizations for } \\
\text { respiratory diseases } \\
\text { among children in an } \\
\text { area with high levels } \\
\text { of environmental } \\
\text { pollution }\end{array}$ & $\begin{array}{l}\text { cross- } \\
\text { sectional }\end{array}$ & $\begin{array}{c}63,7 \% \\
\text { hospitalization/ } \\
90,7 \% \text { pneumonia }\end{array}$ & $<15 y$ & $\mathrm{~N}$ & $\begin{array}{c}\text { male gender; age: }<1 \mathrm{y} ; \\
\text { during the dry season, } \\
\text { the rate of admissions for } \\
\text { respiratory diseases was } \\
10 \% \text { higher than during the } \\
\text { rainy season. }\end{array}$ \\
\hline $\begin{array}{l}\text { Rosa et al. } \\
\text { (2008) [110] }\end{array}$ & $\begin{array}{l}\text { to analyze the } \\
\text { climatic seasonality of } \\
\text { primary care visits for } \\
\text { respiratory disease (RD) } \\
\text { in children }\end{array}$ & $\begin{array}{l}\text { cross- } \\
\text { sectional }\end{array}$ & $\begin{array}{l}32.7 \% \text { respiratory } \\
\text { disease }\end{array}$ & $<15 \mathrm{y}$ & $\mathrm{N}$ & $\begin{array}{l}\text { male gender; age }<5 \mathrm{y} ; \\
\text { primary care visits for } \mathrm{RD} \text {, } \\
\text { especially those due to upper } \\
\text { airway diseases, are related } \\
\text { to the rainy season. }\end{array}$ \\
\hline $\begin{array}{l}\text { Castro et al. } \\
\text { (2007) [111] }\end{array}$ & $\begin{array}{l}\text { to compare the pattern } \\
\text { of asthma spatial } \\
\text { distribution among } \\
\text { children treated at } \\
\text { outpatient services from } \\
2001 \text { to } 2003\end{array}$ & longitudinal & $15 \%$ asthma & $<6 y$ & SE & $\begin{array}{c}\mathrm{PM}_{10^{\prime}} \mathrm{O}_{3} \text {, and } \mathrm{SO}_{2} \\
\text { concentrations exceeded } \\
\text { the } \mathrm{WHO} \text { guidelines by } \\
1.25 \%, 1 \% \text {, and } 7.25 \% \\
\text { respectively; impact of some } \\
\text { local pollution sources, } \\
\text { poor social, environmental } \\
\text { conditions. }\end{array}$ \\
\hline $\begin{array}{l}\text { Junger \& Ponce de } \\
\text { Leon, (2007) [112] }\end{array}$ & $\begin{array}{c}\text { to evaluate the effect } \\
\text { of air pollution on low } \\
\text { birth weight in full term } \\
\text { newborns }\end{array}$ & $\begin{array}{l}\text { cross- } \\
\text { sectional }\end{array}$ & $\begin{array}{l}\mathrm{SO}_{2}>\text { low birth } \\
\text { weight }\end{array}$ & newborn & SE & $\begin{array}{l}\text { first and third trimesters of } \\
\text { pregnancy; especially in } \\
\text { the first months of the year; } \\
\text { suggesting that there is an } \\
\text { association between air } \\
\text { pollution and the incidence } \\
\text { of low birth weight. }\end{array}$ \\
\hline $\begin{array}{l}\text { Nascimento et al. } \\
\text { (2006) [113] }\end{array}$ & $\begin{array}{l}\text { to estimate the } \\
\text { association between } \\
\text { pneumonia admissions } \\
\text { and increased air } \\
\text { pollutants }\end{array}$ & longitudinal & $\begin{array}{c}9,8 \% \\
\text { hostitalization/ } \\
\text { pneumonia }\end{array}$ & $<10 y$ & SE & $\begin{array}{l}\text { the effect of } \mathrm{PM}_{10} \text { remained } \\
\text { statistically significant; air } \\
\text { pollution changes would } \\
\text { have an effect on the } \\
\text { occurrence of children's } \\
\text { respiratory illnesses. }\end{array}$ \\
\hline
\end{tabular}




\begin{tabular}{|c|c|c|c|c|c|c|}
\hline $\begin{array}{l}\text { Farhat et al. } \\
(2005) \text { [114] }\end{array}$ & $\begin{array}{l}\text { to assess the effect of air } \\
\text { pollution on pediatric } \\
\text { respiratory morbidity }\end{array}$ & $\begin{array}{l}\text { cross- } \\
\text { sectional }\end{array}$ & $\begin{array}{l}15 \% \\
\text { hospitalization/ } \\
\text { respiratory } \\
\text { diseases }\end{array}$ & $<13 y$ & SE & $\begin{array}{l}\mathrm{NO}_{2} \text { was positively } \\
\text { associated with all } \\
\text { outcomes; .significant } \\
\text { and positive associations } \\
\text { between air pollution and } \\
\text { respiratory morbidity in } \\
\text { children were found. }\end{array}$ \\
\hline $\begin{array}{l}\text { Saldanha et al. } \\
\text { (2005) [115] }\end{array}$ & $\begin{array}{l}\text { to study variation in } \\
\text { climate (dry or rainy } \\
\text { periods) and health } \\
\text { services use for the } \\
\text { treatment of asthma in } \\
\text { children }\end{array}$ & longitudinal & $\begin{array}{c}10 \% \\
\text { hospitalization/ } \\
\text { asthma }\end{array}$ & $<5 y$ & $\mathrm{CO}$ & $\begin{array}{c}\text { male gender; age: } 1-3 \mathrm{y} ; \\
\text { dry season was correlated } \\
\text { with higher asthma } \\
\text { hospitalization rates with } \\
\text { patients hospitalized: } 52.3 \% \\
\text { versus } 47.7 \% \text { in the rainy } \\
\text { seasons. }\end{array}$ \\
\hline $\begin{array}{c}\text { Medeiros \& } \\
\text { Gouveia, (2005) } \\
{[116]}\end{array}$ & $\begin{array}{l}\text { to study the effect of } \\
\text { air pollution on birth } \\
\text { weight }\end{array}$ & $\begin{array}{l}\text { cross- } \\
\text { sectional }\end{array}$ & $\begin{array}{l}4.6 \% \text { low birth } \\
\text { weight }\end{array}$ & newborn & SE & $\begin{array}{l}\text { maternal exposure to } \mathrm{CO} \text {, } \\
\mathrm{PM}_{10^{\prime}} \text { and } \mathrm{NO}_{2} \text { during the } \\
\text { first trimester of pregnancy } \\
\text { was significantly associated } \\
\text { with decreased birthweight. }\end{array}$ \\
\hline $\begin{array}{l}\text { Nascimento et al. } \\
\text { (2004) [117] }\end{array}$ & $\begin{array}{l}\text { to estimate correlation } \\
\text { between atmospheric } \\
\text { pollutants and the } \\
\text { number of children } \\
\text { admissions by } \\
\text { respiratory disease in } \\
\text { the year } 2001\end{array}$ & longitudinal & $\begin{array}{l}30 \% \\
\text { hospitalization/ } \\
\text { respiratory } \\
\text { disease }\end{array}$ & $<7 y$ & SE & $\begin{array}{l}\text { positive correlation between } \\
\text { the number of admissions } \\
\text { by respiratory disease and } \\
\text { the concentrations of } \mathrm{SO}_{2} \\
\text { and } \mathrm{PM}_{10} .\end{array}$ \\
\hline $\begin{array}{l}\text { Gouveia et al. } \\
\text { (2004) [118] }\end{array}$ & $\begin{array}{l}\text { to explore the } \\
\text { association between } \\
\text { exposure to outdoor } \\
\text { air pollution during } \\
\text { pregnancy and birth } \\
\text { weight }\end{array}$ & $\begin{array}{l}\text { cross- } \\
\text { sectional }\end{array}$ & $\begin{array}{l}5 \% \text { low birth } \\
\text { weight }\end{array}$ & newborn & SE & $\begin{array}{l}\text { female gender; birth weight } \\
\text { exhibited a seasonal } \\
\text { pattern; negative effects of } \\
\text { exposure to } \mathrm{PM}_{10} \text { and CO } \\
\text { during the first trimester; } \\
\text { for a } 1 \mathrm{ppm} \text { increase in mean } \\
\text { exposure to CO during the } \\
\text { first trimester a reduction } \\
\text { of } 23 \mathrm{~g} \text { in birth weight was } \\
\text { estimated. }\end{array}$ \\
\hline $\begin{array}{l}\text { Bakonyi et al. } \\
\text { (2004) [119] }\end{array}$ & $\begin{array}{l}\text { to assess the effects of } \\
\text { air pollution levels on } \\
\text { respiratory morbidity } \\
\text { among children } \\
\text { from } 1999 \text { to } 2000\end{array}$ & longitudinal & $\begin{array}{l}4,5 \%> \\
\text { respiratory } \\
\text { diseases. }\end{array}$ & $<14 y$ & S & $\begin{array}{l}\text { all pollutants }\left(\mathrm{PM}_{10^{\prime}} \mathrm{O}_{3} \text { and }\right. \\
\text { smoke) presented an effect } \\
\text { on respiratory diseases } \\
\text { among children; } \mathrm{NO}_{2} \text { did not } \\
\text { exceed limit for air quality. }\end{array}$ \\
\hline $\begin{array}{c}\text { Botelho et al. (2003) } \\
\text { [120] }\end{array}$ & $\begin{array}{c}\text { to study the } \\
\text { association between } \\
\text { some environmental } \\
\text { factors with the need } \\
\text { for hospitalization } \\
\text { of children with a } \\
\text { diagnosis of acute } \\
\text { respiratory infection } \\
\text { (ARI) }\end{array}$ & $\begin{array}{l}\text { cross- } \\
\text { sectional }\end{array}$ & $\begin{array}{c}7,6 \% \\
\text { hospitalization }\end{array}$ & $<5 y$ & $\mathrm{CO}$ & $\begin{array}{l}\text { the dry season and lower } \\
\text { relative humidity were } \\
\text { associated with increased } \\
\text { pediatric hospitalization rate } \\
\text { due to ARI. }\end{array}$ \\
\hline $\begin{array}{l}\text { Conceição et al. } \\
\text { (2001) [121] }\end{array}$ & $\begin{array}{c}\text { to evaluate the } \\
\text { association between } \\
\text { child mortality and air } \\
\text { pollution from } 1994 \text { to } \\
1997\end{array}$ & $\begin{array}{c}\text { cross- } \\
\text { sectional }\end{array}$ & $\begin{array}{l}>\text { death due } \\
\text { to respiratory } \\
\quad \text { disease }\end{array}$ & $<5 y$ & SE & $\begin{array}{l}\text { Significant associations } \\
\text { between mortality and } \\
\text { concentrations of } \mathrm{CO}, \mathrm{SO}_{2}, \\
\text { and } \mathrm{PM}_{10} \text { were detected. The } \\
\text { estimated proportions of } \\
\text { respiratory deaths attributed } \\
\text { to } \mathrm{CO}, \mathrm{SO}_{2} \text {, and } \mathrm{PM}_{10} \text {, when } \\
\text { considered individually, } \\
\text { were around } 15 \%, 13 \% \text {, and } \\
7 \% \text {, respectively. }\end{array}$ \\
\hline $\begin{array}{l}\text { Braga et al. } \\
\text { (2001) [122] }\end{array}$ & $\begin{array}{l}\text { to investigate the } \\
\text { responses of children } \\
\text { of different ages to air } \\
\text { pollution exposure, } \\
\text { daily records of hospital } \\
\text { admissions }\end{array}$ & $\begin{array}{c}\text { cross- } \\
\text { sectional }\end{array}$ & $\begin{array}{c}<2 \mathrm{y}: 9,4 \% \\
\text { hospitalization/ } \\
>14 \mathrm{y}: 5,1 \% \\
\text { hospitalization }\end{array}$ & $<19 y$ & SE & $\begin{array}{c}\text { age: }<2 \mathrm{y} \text { and } 14-19 \mathrm{y} ; \\
\mathrm{PM}_{10}, \mathrm{O}_{3}, \mathrm{SO}_{2}, \mathrm{CO} \text { and NO} \\
\text { concentrations in ambient } \\
\text { air; daily respiratory } \\
\text { hospital admissions for } \\
\text { children and adolescents } \\
\text { increased with air pollution. }\end{array}$ \\
\hline
\end{tabular}




\begin{tabular}{|c|c|c|c|c|c|c|}
\hline $\begin{array}{c}\text { Gouveia N.; } \\
\text { Fletcher T. (2000) } \\
\text { [123] }\end{array}$ & $\begin{array}{l}\text { to investigate the } \\
\text { short term effects of } \\
\text { air pollution on the } \\
\text { respiratory morbidity } \\
\text { of children }\end{array}$ & $\begin{array}{l}\text { cross- } \\
\text { sectional }\end{array}$ & > hospitalization & $<5 y$ & SE & $\begin{array}{c}\text { age: }<1 \mathrm{y} \text {; daily admissions } \\
\text { of children in hospital for } \\
\text { total respiratory disease } \\
\text { and pneumonia showed } \\
\text { significant increases } \\
\text { associated with } \mathrm{O}_{3}(5-8 \%), \\
\mathrm{NO}_{2}(9 \%) \text {, and with } \mathrm{PM}_{10} \\
(9 \%) .\end{array}$ \\
\hline $\begin{array}{c}\text { Lin et al. } \\
\text { (1999) [124] }\end{array}$ & $\begin{array}{l}\text { to report the } \\
\text { association between } \\
\text { air pollution and } \\
\text { pediatric respiratory } \\
\text { emergency visits in the } \\
\text { southeast region }\end{array}$ & $\begin{array}{c}\text { cross- } \\
\text { sectional }\end{array}$ & $\begin{array}{l}20 \% \\
\text { hospitalization/ } \\
\text { respiratory } \\
\text { emergency visits }\end{array}$ & $<13 y$ & SE & $\begin{array}{l}\text { significant associations } \\
\text { between the increase of } \\
\text { respiratory emergency } \\
\text { visits and air pollution } \\
\text { were observed; the most } \\
\text { robust associations were } \\
\text { observed with } \mathrm{PM}_{10} \text {, and to } \\
\text { a lesser extent with } \mathrm{O}_{3 ;} \text { air } \\
\text { pollution is a substantial } \\
\text { pediatric health concern. }\end{array}$ \\
\hline
\end{tabular}

In the subtheme "exposure to chemical micropollutants", 15 articles (Tab. VI) were identified. In the analyzed articles, pesticides, mercury, arsenic and lead were considered potential risk factors to children's health.

Researchers have suggested the relation between the use of agrochemicals and adverse events in children and adolescents. The findings showed that prenatal pesticide exposure is a risk factor to premature birth and inadequate maturation [128] and to some types of cancer in children. Acute Myeloid
Leukemia (AML) and Acute Lymphocytic Leukemia (ALL) in young child were significantly associated with periconceptional exposure to pesticides (esbiothrin, tetramethrin, d-allethrin and d-phenothrin) [126]. Curvo [125] analyzed the positive prevalence of morbimortality due to cancer in adolescents in cities of the CO region, where there was an increase in grain harvesting and $48.91 \%$ of agrochemicals used were shown to be carcinogenic.

\begin{tabular}{|c|c|c|c|c|c|c|}
\hline \multicolumn{7}{|c|}{ Exposure to chemicals micropollutants } \\
\hline Reference & Purpose & Type of Study & Health Effects & Age & Region & Outcomes \\
\hline $\begin{array}{l}\text { Curvo et al. } \\
\text { (2013) [125] }\end{array}$ & $\begin{array}{l}\text { to analyze the association } \\
\text { between the agricultural } \\
\text { use of pesticides and } \\
\text { cancer morbidity and } \\
\text { mortality in children and } \\
\text { adolescents }\end{array}$ & longitudinal & $\begin{array}{l}>\text { morbidity } \\
>\text { mortality }\end{array}$ & $<19 y$ & $\mathrm{CO}$ & $\begin{array}{l}\text { male gender; the average use of pesticides in } \\
\text { the counties showed a statistically significant } \\
\text { association for both morbidity as for mortality } \\
\text { for cancer children and adolescents, with } 95 \% \\
\text { confidence interval. }\end{array}$ \\
\hline $\begin{array}{l}\text { Ferreira et al. } \\
(2013)[126]\end{array}$ & $\begin{array}{l}\text { to investigate the } \\
\text { association between } \\
\text { pesticide exposure during } \\
\text { pregnancy and leukemia } \\
\text { in children }\end{array}$ & longitudinal & $\begin{array}{l}48.4 \% \text { of } \\
\text { AML/ } 47.6 \% \\
\text { of ALL }\end{array}$ & $<2 \mathrm{y}$ & $\begin{array}{l}\text { NE, CO, SE } \\
\quad \text { e S }\end{array}$ & $\begin{array}{c}\text { male gender; associations with ever use of } \\
\text { pesticide exposure during pregnancy may be } \\
\text { involved in the etiology of acute leukemia in } \\
\text { children. }\end{array}$ \\
\hline $\begin{array}{l}\text { Dutra et al. } \\
\text { (2012) [127] }\end{array}$ & $\begin{array}{l}\text { to study a longitudinal } \\
\text { assessment of mercury } \\
\text { exposure in schoolchildren } \\
\text { in an urban area }\end{array}$ & longitudinal & $\begin{array}{c}1 \mu \mathrm{g} / \mathrm{g}- \\
8.22 \mu \mathrm{g} / \mathrm{g} \text { hair } \\
10 \mu \mathrm{g} / \mathrm{L}- \\
60 \mu \mathrm{g} / \mathrm{L} \\
\text { blood level at } \\
\text { birth }\end{array}$ & $8-10 y$ & $\mathrm{~N}$ & $\begin{array}{c}\text { male gender; age: } 8 \text { y; there was a significant } \\
\text { increase in blood mercury from } 2004 \text { to } 2006 \\
\text { (p }<0.001 \text { ), exposure through air pollution; } \\
\text { the main exposure to mercury was during } \\
\text { pregnancy. }\end{array}$ \\
\hline $\begin{array}{l}\text { Cremonese et al. } \\
\text { (2012) [128] }\end{array}$ & $\begin{array}{l}\text { to investigate potential } \\
\text { relations between } \\
\text { per capita pesticide } \\
\text { consumption and adverse } \\
\text { events in live born infants }\end{array}$ & longitudinal & $\begin{array}{l}\text { > premature } \\
\text { birth } \\
\text { low Apgar } \\
\text { score }\end{array}$ & newborn & S & $\begin{array}{l}\text { prenatal pesticide exposure is a risk factor for } \\
\text { adverse pregnancy events such as premature } \\
\text { birth and inadequate maturation. }\end{array}$ \\
\hline $\begin{array}{l}\text { Ferron et al. } \\
\text { (2012) [129] }\end{array}$ & $\begin{array}{l}\text { to estimate the prevalence } \\
\text { of lead poisoning in } \\
\text { children and to identify } \\
\text { associated factors, as well } \\
\text { as possible local sources of } \\
\text { contamination }\end{array}$ & $\begin{array}{l}\text { cross- } \\
\text { sectional }\end{array}$ & $\begin{array}{c}16 \% \text { blood } \\
\text { lead levels } \geq \\
10.0 \mu \mathrm{g} / \mathrm{dL}\end{array}$ & $0-5 y$ & $\mathrm{~S}$ & $\begin{array}{l}\text { male gender; age: } 2,6 \text { y; waste recylcing } \\
\text { activities.; soil, and air pollution. }\end{array}$ \\
\hline
\end{tabular}




\begin{tabular}{|c|c|c|c|c|c|c|}
\hline $\begin{array}{l}\text { Sakuma et al. } \\
\text { (2010) [130] }\end{array}$ & $\begin{array}{l}\text { to assess children } \\
\text { exposure to arsenic from } \\
\text { environmental sources in } \\
\text { a region of lead mining } \\
\text { area }\end{array}$ & $\begin{array}{c}\text { cross- } \\
\text { sectional }\end{array}$ & $\begin{array}{l}\text { hight level } \\
\text { of urinary } \\
\text { arsenic in one } \\
\text { group }\end{array}$ & $7-14 y$ & SE e $S$ & $\begin{array}{l}\text { anthropic contamination may explain the } \\
\text { higher urinary arsenic values. }\end{array}$ \\
\hline $\begin{array}{l}\text { Olympio et al. } \\
\text { (2010) [131] }\end{array}$ & $\begin{array}{l}\text { to analyze household risk } \\
\text { factors associated with } \\
\text { high lead levels in surface } \\
\text { dental enamel } \\
\text { in adolescents living in } \\
\text { poor neighborhoods }\end{array}$ & $\begin{array}{l}\text { cross- } \\
\text { sectional }\end{array}$ & $\begin{array}{l}\text { high dental } \\
\text { enamel lead } \\
\text { levels }\end{array}$ & $14-18$ y & SE e $S$ & $\begin{array}{l}\text { male gender; living in or close to a } \\
\text { contaminated area and member of the } \\
\text { household worked in the manufacturing of } \\
\text { paints, paint pigments, ceramics or batteries. }\end{array}$ \\
\hline $\begin{array}{l}\text { Mattos et al. } \\
\text { (2009) [132] }\end{array}$ & $\begin{array}{l}\text { to identify the } \\
\text { contamination sources and } \\
\text { potential risk factors of the } \\
\text { exposure in children from } \\
\text { an economically deprived } \\
\text { community }\end{array}$ & $\begin{array}{l}\text { cross- } \\
\text { sectional }\end{array}$ & $\begin{array}{c}40 \% \mathrm{~Pb}-\mathrm{S}> \\
6 \mu \mathrm{g} / \mathrm{dL} \\
5 \% \mathrm{~Pb}-\mathrm{S}>10 \\
\mu \mathrm{g} / \mathrm{dL}\end{array}$ & $0-16 y$ & $\mathrm{SE}$ & $\begin{array}{l}\text { male gender; the carcinogenic risk factor for } \\
\text { ingestion was about } 4 \text { times; sociodemographic } \\
\text { aspects: low income, sewer destiny, dust and } \\
\text { contaminated soil. }\end{array}$ \\
\hline $\begin{array}{l}\text { Farias et al. } \\
(2008)[133]\end{array}$ & $\begin{array}{l}\text { to assess total Hg levels } \\
\text { in children's hair from a } \\
\text { coastal population }\end{array}$ & $\begin{array}{l}\text { cross- } \\
\text { sectional }\end{array}$ & $\begin{array}{l}\text { low Hg levels } \\
0.04 \mathrm{mg}^{-k^{-1}}\end{array}$ & $4-12$ y & SE & $\begin{array}{l}\text { the values were well below the level set } \\
\text { by World Health Organization for an adult } \\
\text { population unexposed to } \mathrm{Hg}\left(2.0 \mathrm{mg} \cdot \mathrm{kg}^{-1}\right) .\end{array}$ \\
\hline $\begin{array}{l}\text { Santos et al. } \\
(2007)[134]\end{array}$ & $\begin{array}{l}\text { to evaluate transplacental } \\
\text { mercury transfer by } \\
\text { measuring Hg in blood } \\
\text { samples of mothers and } \\
\text { newborns (umbilical cord) }\end{array}$ & $\begin{array}{l}\text { cross- } \\
\text { sectional }\end{array}$ & $\begin{array}{l}\text { Hg: } 16.68 \mu \mathrm{g} / \mathrm{L} \\
\text { in } \\
\text { newborns }\end{array}$ & newborn & $\mathrm{N}$ & $\begin{array}{l}\text { maternal blood Hg showed a strong positive } \\
\text { correlation with age and a positive (but weak) } \\
\text { correlation with frequency of fish consumption; } \\
\text { correlation between maternal and cord blood } \\
\text { Hg levels) was strongly positive. }\end{array}$ \\
\hline $\begin{array}{c}\text { Rodrigues \&; } \\
\text { Carnier, (2007) } \\
{[\text { [135] }}\end{array}$ & $\begin{array}{l}\text { to investigate the general } \\
\text { development and the } \\
\text { areas in imbalance of } \\
\text { children with levels of lead } \\
\text { contamination in the blood } \\
\text { above } 10 \mu \mathrm{g} / \mathrm{dl}\end{array}$ & $\begin{array}{l}\text { cross- } \\
\text { sectional }\end{array}$ & $\begin{array}{l}\text { important } \\
\text { imbalances in } \\
\text { Cognition and } \\
\text { Language }\end{array}$ & $1-5 y$ & SE & $\begin{array}{l}\text { the reduced number of children and the } \\
\text { absence of data from a control group made } \\
\text { it difficult to confirm the observed results } \\
\text { concerning general development following lead } \\
\text { contamination, though it is consistent with the } \\
\text { research literature. }\end{array}$ \\
\hline $\begin{array}{l}\text { Padula et al. } \\
\text { (2006) [136] }\end{array}$ & $\begin{array}{l}\text { to evaluate the condition } \\
\text { of all children living } \\
\text { in close proximity to a } \\
\text { battery factory }\end{array}$ & $\begin{array}{l}\text { cross- } \\
\text { sectional }\end{array}$ & $\begin{array}{c}36,8 \% \geq \\
10 \mu \mathrm{g} / \mathrm{dL} /> \\
\text { neurological } \\
\quad \text { risk }\end{array}$ & $0-12 y$ & SE & $\begin{array}{c}\text { blood lead levels in the control group were } \\
\text { lower than those presented by the exposed } \\
\text { group }(\mathrm{p}<0.05) 314 \text { children with blood lead } \\
\text { rates higher than those acceptable to the CDC } \\
(10 \mu \mathrm{gPb} / \mathrm{dl} \text { blood. }\end{array}$ \\
\hline $\begin{array}{l}\text { Tavares et al. } \\
\text { (2005) [137] }\end{array}$ & $\begin{array}{l}\text { to investigate the use of } \\
\text { a battery of neurological } \\
\text { development tests in } \\
\text { two groups of riverine } \\
\text { children }\end{array}$ & longitudinal & $\begin{array}{c}\text { higher } \\
\text { exposure to } \\
\text { MeHg }=5.37 \pm \\
3.35 \mu \mathrm{g} / \mathrm{g}\end{array}$ & $3-7 y$ & $\mathrm{~N}$ & $\begin{array}{l}\text { in the clinical examination, no signs and } \\
\text { symptoms were found that could jointly reflect } \\
\text { a clinical picture characteristic of mercury } \\
\text { poisoning; }\end{array}$ \\
\hline $\begin{array}{l}\text { Carvalho et al. } \\
\text { (2003) [138] }\end{array}$ & $\begin{array}{l}\text { to determine the blood } \\
\text { lead levels in children } \\
\text { living in an inactive lead } \\
\text { foundry and to identify } \\
\text { factors associated with } \\
\text { differences in these levels }\end{array}$ & $\begin{array}{c}\text { cross- } \\
\text { sectional }\end{array}$ & $\begin{array}{c}\mathrm{Pb}: 17.1 \pm 7.3 \\
\mathrm{mg} / \mathrm{dL}\end{array}$ & $1-4 y$ & $\mathrm{NE}$ & $\begin{array}{l}\text { visible presence of scum surrounding the } \\
\text { home, family history of lead poisoning, and } \\
\text { malnutrition; the environmental legacy of the } \\
\text { lead foundry, represent a relevant risk factor } \\
\text { for increased blood lead levels in children, } \\
\text { especially those presenting pica. }\end{array}$ \\
\hline $\begin{array}{l}\text { Grandjean et al. } \\
\text { (1999) [139] }\end{array}$ & $\begin{array}{l}\text { to carry out cross-sectional } \\
\text { studies in four comparable } \\
\text { riverine communities } \\
\text { that had exposure to } \\
\text { methylmercury }\end{array}$ & $\begin{array}{c}\text { cross- } \\
\text { sectional }\end{array}$ & $\begin{array}{l}80 \% \text { hair- } \\
\text { mercury }>10 \\
\text { microg/g }\end{array}$ & $7-12 y$ & $\mathrm{~N}$ & $\begin{array}{l}\text { the current mercury pollution seems } \\
\text { sufficiently severe to cause adverse effects on } \\
\text { brain development. }\end{array}$ \\
\hline
\end{tabular}

Another chemical contaminant related with Brazilian children's health living in several parts of the Amazon basin (N Region) has been mercury, used in the gold extraction process [133] and resulting in the contamination of freshwater fish with methylmercury [139]. Children can be subjected to mercury exposure through: prenatal transfer across the placenta [134] with positive correlation with mother's frequency of fish consumption; breastfeeding, by ingesting breast milk containing mercury; and a diet rich in fish [127] with possible adverse effects on brain development [139]. Riverine children presented higher exposure to methyl mercury (one organic form of mercury) as compared to other communities in the Brazilian Amazon [137], but in the clinical examination, no signs and symptoms were found that could jointly reflect a clinical picture characteristic of poisoning.

Concerning the prevalence of lead poisoning, studies found blood lead levels $\geq 10.0 \mu \mathrm{g} / \mathrm{dl}$, in children, associated with waste recycling [129] and residing close proximity to a battery factory [136]. Another study showed a strong association between adolescents with high dental enamel lead levels living in or close a contaminated area [131]. In those three studies, the high lead levels seemed not affect the child population health. Another 
study showed a strong association between adolescents with high dental enamel lead levels living in or close a contaminated area [131]. Sakuma et al. [130] reported that contamination from lead in a former mining area may explain the higher urinary arsenic values among the children living nearly, despite the median arsenic values do not warrant immediate health concern. Conversely, researchers suggested relations among important imbalances in cognition and language in early childhood with indices of contamination for lead up $10.0 \mu \mathrm{g} / \mathrm{dl}$ to $45.40 \mu \mathrm{g} / \mathrm{dl}$ [135], and also neurological risk factor of exposure to lead on dust and by ingestion, in children from an economically deprived community [132] especially in those presenting pica and malnutrition [138].
On the third subtheme "exposure to other biological agents", we used 13 articles (Tab. VII). Authors have studied the importance of early diagnosis of and correct treatment for dengue fever and malaria in endemic regions. The prevalence of dengue in children living in areas in the N Region [141, 142], CO Region [145] and SE Region [147] have led to a disruption of routine health services, demanding further efforts towards providing technical training to health professionals working on the frontline of dengue treatment in children's patient care. As for malaria, researches had investigated children and adolescents who live in the $\mathrm{N}$ region $[151,152]$. The lethality was $1.6 \%$ and besides the common symptoms of malaria triad (fever, chills and headache) they had among others like pallor, anemia, myalgia, vomiting and some degree of malnourishment [151], and there was a prevalence of malaria among adolescents [152].

\begin{tabular}{|c|c|c|c|c|c|c|}
\hline \multicolumn{7}{|c|}{ Exposure to other biological agents } \\
\hline Reference & Purpose & $\begin{array}{l}\text { Type of } \\
\text { Study }\end{array}$ & Health Effects & Age & Region & Outcomes \\
\hline $\begin{array}{l}\text { (Cruz et al } \\
\text { 2013) [140] }\end{array}$ & $\begin{array}{l}\text { To describe an } \\
\text { extremely } \\
\text { uncommon outbreak } \\
\text { of eye lesions in a } \\
\text { specific area of the } \\
\text { Brazilian Amazonia }\end{array}$ & $\begin{array}{c}\text { cross- } \\
\text { sectional }\end{array}$ & $57,8 \%$ eye & $11.6 \pm 6.5 \mathrm{y}$ & $\mathrm{N}$ & $\begin{array}{l}83 \text { eyes were affected; the most common } \\
\text { lesions were corneal opacities observed } \\
\text { in } 34 \text { eyes and conjunctival nodules } \\
\text { diagnosed in } 12 \text { eyes; the necessity } \\
\text { of caution when tourists interact with } \\
\text { unfamiliar ecosystems, especially in } \\
\text { disturbed environments. }\end{array}$ \\
\hline $\begin{array}{l}\text { (Costa CA \& } \\
\text { Façanha GP. } \\
\text { 2011) [141] }\end{array}$ & $\begin{array}{l}\text { to identify dengue } \\
\text { virus serotypes, } \\
\text { in } 2008 \text { in infant } \\
\text { population }\end{array}$ & $\begin{array}{c}\text { cross- } \\
\text { sectional }\end{array}$ & $17 \%$ positive & $0-10 y$ & $\mathrm{~N}$ & $\begin{array}{l}\text { occurrence of other febrile illnesses that } \\
\text { need to be determined; all zones and } \\
\text { eleven districts in the study had positive } \\
\text { cases. }\end{array}$ \\
\hline $\begin{array}{l}\text { (Rocha LA. } \\
\text { \& Tauil PL. } \\
\text { 2009) [142] }\end{array}$ & $\begin{array}{l}\text { to present the clinical } \\
\text { and epidemiological } \\
\text { characteristics of } \\
\text { children affected by } \\
\text { dengue, in } 2006 \text { and } \\
2007\end{array}$ & $\begin{array}{c}\text { cross- } \\
\text { sectional }\end{array}$ & $\begin{array}{l}46,9 \% \text { positive }(2006) \\
57,7 \% \text { positive }(2007)\end{array}$ & $0-14 y$ & $\mathrm{~N}$ & $\begin{array}{l}\text { although the hemorrhagic form was } \\
\text { almost three times more frequent in } 2007 \text {, } \\
\text { the mortality rate was lower; } 2006 \text { - the } \\
\text { highest incidence was in children under } 1 \\
\text { year; } 2007 \text { - there were a predominance } \\
\text { in children } 10-14 \text { years. }\end{array}$ \\
\hline $\begin{array}{l}\text { (Guerra et } \\
\text { al. 2007) } \\
\text { [143] }\end{array}$ & $\begin{array}{l}\text { to evaluate } \\
\text { factors related to } \\
\text { the occurrence } \\
\text { of cutaneous } \\
\text { leishmaniasis in } \\
\text { children }\end{array}$ & longitudinal & $\begin{array}{c}34 \% \text { positive/ } \\
11-14 \mathrm{y}\end{array}$ & $0-14 y$ & $\mathrm{~N}$ & $\begin{array}{l}\text { activities in the forest around the houses } \\
\text { and the living situation near the primary } \\
\text { forest; cases in very young children, } \\
\text { suggested transmission in and around } \\
\text { the house, and in a few cases, children } \\
\text { entering the forest. }\end{array}$ \\
\hline $\begin{array}{l}\text { (Volkmer- } \\
\text { Ribeiro et } \\
\text { al. 2006) } \\
\text { [144] }\end{array}$ & $\begin{array}{l}\text { to carry out aiming to } \\
\text { detect sponge spicules } \\
\text { in surgically removed } \\
\text { ocular lesions }\end{array}$ & $\begin{array}{c}\text { cross- } \\
\text { sectional }\end{array}$ & $\begin{array}{l}100 \% \text { freshwater } \\
\text { sponge spicules }\end{array}$ & $8-13 y$ & $\mathrm{~N}$ & $\begin{array}{l}\text { freshwater sponge spicules Drulia } \\
\text { uruguayensis and D. ctenosclera may be } \\
\text { new etiological agent of ocular pathology } \\
\text { injuries that occurred in a town at the } \\
\text { right bank of Araguaia river. }\end{array}$ \\
\hline $\begin{array}{l}\text { (Campagna } \\
\text { et al. 2006) } \\
\quad[145]\end{array}$ & $\begin{array}{l}\text { to study the etiology } \\
\text { of exanthema cases, } \\
\text { in children seen in the } \\
\text { emergency room in a } \\
\text { region where dengue } \\
\text { is endemic }\end{array}$ & $\begin{array}{l}\text { cross- } \\
\text { sectional }\end{array}$ & $\begin{array}{l}\text { 77,5\% positive for } \\
\text { dengue fever }\end{array}$ & $0-13 y$ & $\mathrm{CO}$ & $\begin{array}{l}\text { the most common clinical manifestations } \\
\text { among the dengue patients were: fever, } \\
\text { itching, prostration, myalgia and positive } \\
\text { tourniquet test results; constant control } \\
\text { of epidemiological and serological } \\
\text { surveillance of exanthematous diseases is } \\
\text { necessary. }\end{array}$ \\
\hline
\end{tabular}




\begin{tabular}{|c|c|c|c|c|c|c|}
\hline $\begin{array}{c}\text { (Ampuero } \\
\text { et al. 2005) } \\
{[146]}\end{array}$ & $\begin{array}{l}\text { to identify risk } \\
\text { factors for cutaneous } \\
\text { leishmaniasis } \\
\text { transmission in } \\
\text { children in an } \\
\text { endemic area }\end{array}$ & longitudinal & $33 \%$ positive & $0-5 y$ & $\mathrm{NE}$ & $\begin{array}{l}\text { no evidence of association between } \\
\text { the disease and other risk factors such } \\
\text { as child's habits inside or outside the } \\
\text { house, domiciliary or peridomiciliary } \\
\text { characteristics, or presence of vectors or } \\
\text { probable reservoir animals; the hypothesis } \\
\text { is that humans serve as both the reservoir } \\
\text { and source of infection for this age group. }\end{array}$ \\
\hline $\begin{array}{l}\text { (Rodrigues } \\
\text { et al. 2005) } \\
\text { [147] }\end{array}$ & $\begin{array}{l}\text { to identify clinical } \\
\text { characteristics } \\
\text { indicative of dengue } \\
\text { and to evaluate } \\
\text { the applicability to } \\
\text { children of the Health } \\
\text { Ministry criteria for } \\
\text { suspected case }\end{array}$ & $\begin{array}{c}\text { cross- } \\
\text { sectional }\end{array}$ & $50,4 \%$ positive & $1-12 y$ & SE & $\begin{array}{l}\text { only exanthema was more often associated } \\
\text { with dengue; the Health Ministry criteria } \\
\text { for suspected cases was shown to be } \\
\text { of little use, particularly with smaller } \\
\text { children and during periods of reduced } \\
\text { incidence. }\end{array}$ \\
\hline $\begin{array}{l}\text { (Coelho et } \\
\text { al. } 2004 \text { ) } \\
{[148]}\end{array}$ & $\begin{array}{l}\text { to perform a } \\
\text { seroepidemiological } \\
\text { survey in order to } \\
\text { detect anti-toxocara } \\
\text { antibodies among } \\
\text { schoolchildren }\end{array}$ & $\begin{array}{l}\text { cross- } \\
\text { sectional }\end{array}$ & $38,3 \%$ positive & $2-8 y$ & SE & $\begin{array}{l}\text { children living in the city outskirts where } \\
\text { the socioeconomic conditions were worse } \\
\text { than in the central region of the city; } \\
\text { enteroparasitism and pet dogs and/or } \\
\text { cats without vermifuge treatment. }\end{array}$ \\
\hline $\begin{array}{l}\text { (Bucaretchi } \\
\text { et al. 2002) } \\
\text { [149] }\end{array}$ & $\begin{array}{l}\text { to describe the clinical } \\
\text { and some laboratory } \\
\text { aspects of bites } \\
\text { caused by Crotalus } \\
\text { durissus ssp snakes in } \\
\text { children }\end{array}$ & longitudinal & $\begin{array}{l}87 \% \text { palpebral ptosis/ } \\
74,19 \% \text { myalgia }\end{array}$ & $1-14$ y & SE & $\begin{array}{l}\text { occurred from November to April, } \\
\text { in rural areas, including around the } \\
\text { home; laboratory tests suggesting } \\
\text { rhabdomyolysis included an increase in } \\
\text { total blood creatine kinase and lactate } \\
\text { dehydrogenase levels and myoglobinuria; } \\
\text { no deaths were recorded. }\end{array}$ \\
\hline $\begin{array}{l}\text { (Bucaretchi } \\
\text { et al. 2001) } \\
\text { [150] }\end{array}$ & $\begin{array}{l}\text { to describe the clinical } \\
\text { aspects and outcome } \\
\text { of bites caused by } \\
\text { Bothrops spp. snakes } \\
\text { in children }\end{array}$ & longitudinal & $\begin{array}{c}94,5 \% \text { edema/ } \\
94,5 \% \text { pain/ } \\
73,4 \% \text { ecchymosis }\end{array}$ & $1-14 y$ & SE & $\begin{array}{l}\text { most accidents occurred from October to } \\
\text { March, in rural areas, including around } \\
\text { the home. The main clinical complications } \\
\text { observed were local infection (15.1\%), } \\
\text { compartment syndrome (4.1\%), gangrene } \\
(1.4 \%) \text { and acute renal failure (1.4\%). }\end{array}$ \\
\hline $\begin{array}{l}\text { (Noronha } \\
\text { et al. 2000) } \\
\text { [151] }\end{array}$ & $\begin{array}{l}\text { to study the clinical } \\
\text { characteristics of } \\
\text { falciparum malaria } \\
\text { among children } \\
\text { treated at a reference } \\
\text { center }\end{array}$ & $\begin{array}{c}\text { cross- } \\
\text { sectional }\end{array}$ & $\begin{array}{l}98,4 \% \text { fever/ } \\
80,3 \% \text { headache/ } \\
68,9 \% \text { chills/ }\end{array}$ & $0-14 y$ & $\mathrm{~N}$ & $\begin{array}{l}\text { 91.5\% patients had uncomplicated malaria } \\
\text { and the lethality was } 1.6 \% \text {; most children } \\
\text { (85.2\%) have been infected in rural areas, } \\
\text { although there was urban transmission } \\
(13.1 \%) \text {, mainly in the suburbs. }\end{array}$ \\
\hline $\begin{array}{l}\text { (Ventura et } \\
\text { al. 1999) } \\
\text { [152] }\end{array}$ & $\begin{array}{l}\text { to evaluate } \\
\text { epidemiological, } \\
\quad \text { clinical and } \\
\text { laboratory features } \\
\text { of Plasmodium vivax } \\
\text { malaria in children } \\
\text { and adolescents }\end{array}$ & $\begin{array}{c}\text { cross- } \\
\text { sectional }\end{array}$ & $\begin{array}{c}97 \% \text { fever } / 91 \% \text { chills/ } \\
85 \% \text { pallor/ } \\
89,2 \% \text { anemia }\end{array}$ & $0-14 y$ & $\mathrm{~N}$ & $\begin{array}{l}\text { adolescents (37\%) probably working on } \\
\text { the farm and mining to help support their } \\
\text { family ; primary infection in } 80 \% \text { of the } \\
\text { patients; } 13,6 \% \text { malarial triad. }\end{array}$ \\
\hline
\end{tabular}

Another cause of illnesses in children related to regional socio-environmental factors are accidents that happen in area contiguous to the household. Authors detected anti-toxocara antibodies positive among schoolchildren living in a house with a yard and/or unpaved street and there was also an association between a seronegative ELISA test and previous treatment of pet dogs and/or cats with vermifuge [148]. The occurrence of cutaneous leishmaniasis in children living in N and NE Region, suggested transmission in and around the house, and in a few cases, children were entering the forest [143] or presence of a family member with a history of these disease [146]. Especially in rural areas in the SE Region where there are deforestation and residences near natural forest children can be stung by snakes and show clinical complications $[149,150]$. Clinical researches [140, 144] detected important ocular lesions caused by freshwater sponges species Drulia uruguayensis and Drulia ctenosclera, in school age children who swam in some rivers near their homes, in the Brazilian Amazon. These works revealed that freshwater sponge spicules may be a dangerous etiological agent of ocular pathology to kids that swim on those rivers.

\section{Discussion}

\section{Home Life}

We can summarize, in relation to infant exposure to risk factors in the domicile lives that there are three direct threats: toxic substances, parental smoking and the burning of domiciliary biomass and living conditions at home.

According to our research, the exposure to toxic agents at 
home, in children younger than 5 years of age, was mostly due to household cleaning substances, pesticides and the inappropriate use of medicine. This result is very close to the conclusion of studies conducted by Mowry et al. [153], which suggests there is a need to create stronger national prevention campaigns focused on the inappropriate conditions in which products are purchased, on explaining about packaging of those agents, on raising awareness of the risks of the domestic environment and of the placement of the hazardous substances, which, in the research, were in the children's reach.

The present review has clearly shown the harmful effect of parent smoking on the respiratory health of the children and has identified three critical and biologically relevant windows of exposure to the adverse effect of second-hand smoking on children: i) in-utero, with a negative impact on the anthropometric measures of the newborn, confirmed also by Salihu and Wilson [154]; ii) in the first two years of life, when the respiratory tract infection rates are much higher and maternal smoking has a higher effect because the children stay a longer time at home in direct contact with the grownups [155]; iii) after the first two years, when respiratory diseases like bronchiolitis, asthma or pneumonia are more common, elevating the children morbidity.

Confirming that data, the research done by Gupta et al. [156] showed that, from over 40 studies, all but one have reported an increased risk among children whose parents smoke, and pooling the studies' results, children whose mothers smoke are estimated to have a 1.7-fold higher risk of these illnesses than children of nonsmoking mothers while paternal smoking alone causes a 1.3fold increase in risk. Heinrich [157], in an review of the influence of indoor factors in dwellings on the development of childhood asthma, corroborates the above data, suggesting that one of most consistent findings for the cause of asthma in childhood is related to exposure to environmental tobacco smoke.

But even worse than exposing children to tobacco smoke is contaminating them with third-hand smoking - THS [158], which according to Ramírez et al. [159] can cause changes to the DNA and cancer, as the nicotine residues provoke on lesions that break the molecule bonds responsible for transmitting the genetic code. In our research, we did not find any Brazilian study about so important theme.

Another important point to discuss is the smoke resulting from burning the domiciliary biomass and its repercussions on children's respiratory system. In Brazil, a country of vast socioeconomic contrasts, gas cylinders are expensive and/or hard to get, which makes the lower classes use firewood and coal in ovens. Data from the Tolmasquim \& Guerreiro [160] shows that firewood is the second highest source of residential energy consumption in the country, accounting for $33.9 \%$ of all energy used in domestic supply. The WHO [14] reinforces that data by confirming that worldwide, around 3 billion people cook and heat their homes using open fires and simple stoves burning biomass like wood and coal. The most serious piece of data is that more than $50 \%$ of premature deaths among children under 5 are due to pneumonia caused by particulate matter (soot) inhaled from household air pollution [14]. Even with such relevant information, we found only one research done on Brazil about this risk effects: the use of wood stove for cooking as a major factor associated for recurrent wheezing in children [41].

\section{Social - Sanitation and Socio-environmental Factors}

In this group, we worked with information about the prevalence of diseases children suffered that are related to sanitary conditions, like having no water supply waste. This data confirm the available scientific evidence that the dissemination of parasitosis and morbidity due to diarrhea are affected by environmental changes, high population concentration, poor hygiene and when faeces are disposed of improperly which can then contaminate food or other humans - person-to-person transmission [161].

Studies have shown that intestinal parasites like Ascaris lumbricoides and Trichuris trichiura are common in daycares, preschoolers and elementary school-age children. The CDC [162] corroborates that data by declaring that the Ascaris infection is one of the most common intestinal worm infections. It is found in association with poor personal hygiene, poor sanitation, and in places where human feces are used as fertilizer. According to the CDC [162], heavy infestations can affect the nutritional balance and harm the children's growth. Our study confirmed that alterations to the anthropometric state [76] and malnutrition of children can be secondary to parasitosis and are intimately associated to the insalubrious environment [62] especially in household that do not have a proper waste management and collection of solid residues [78]. So improving the living conditions of the deprived population, as well as giving them access to a better healthcare are essential measures to cause a positive change in the situation shown above.

We have seen the general mortality and hospital morbidity rates due to diarrheic diseases in children under five years of age have been decreasing in Brazil. However, the Northern and Northeastern Regions, areas with the lower HDI in the country, still show the highest coefficients of mortality and the highest percentage of admittance of children under one year of age [49]. Even though Brazil has almost $13 \%$ of all superficial hydric resources of the planet, it is a country where a vast number of people do not have bathroom inside the household, corresponding to 7.2 million people [163]. Thirty four million people have no access to canalized water; 103 million people have no access to a waste disposal system, and only $38.7 \%$ of the generated waste is treated [164]. The NE Region is where the lack of a sewerage system is most dire, and approximately 15.3 million people are affected by the lack of sanitation [165]. The regional heterogeneity of the coefficients of mortality due to diarrhea reflects that socioeconomic and cultural inequality, as well as the difficulty the lowest classes have in getting access to healthcare and to sanitation.

\section{Regional - Regional environmental factors}

The relationship between the air pollution and the climatic variables has been a growing concern also on a regional level in 
Brazil due to the potential effects on human health, as it is also responsible for the increase of the number of the cases and the gravity of acute respiratory infection in children under five years of age. As a country with a tropical climate, throughout the year the weather is mild and, on occasion, very hot, with marked periods of rain and drought. The reduction of the relative humidity of the air below $30 \%$ is considered dangerous to the integrity of the airways, especially for a susceptible population [110].

Some viruses have a seasonal behavior, with a higher frequency in the rain season and during sharp climatic changes, which also causes the precipitation of the particulate matter from the atmosphere in big cities, increasing the number of cases of pneumonia, asthma and bronchiolitis in vulnerable children. D'Amato et al. [166] confirm this data and report that climate change represents a massive direct threat to respiratory health by promoting or aggravating respiratory diseases or indirectly by increasing exposure to risk factors for respiratory diseases. More than $85 \%$ of all fires in Brazil during the dry season are concentrated in the Amazon region, accounting for a long-term source of emission of gases from the burning of biomasses during the dry season $[167,168]$. Children and adolescents living in the Subequatorial Brazilian Amazon region exposed to high levels of $\mathrm{PM}_{2.5}$ had toxicological risk quotients comparable to or higher than in children living in metropolitan regions where the $\mathrm{PM}_{2.5}$ air pollution is above the recommended limits to human health [169].

In contrast to large cities in other countries where the main sources of aerosol particles are emissions linked to fossil fuel combustion [170], in Brazil, sugarcane burning contributed to $60 \%$ of the fine-mode aerosol mass [171] and can contribute to the aggravation of asthma and rhinitis episodes in susceptible children [101].

We have also found significant and positive relations between air pollution and respiratory morbidity in children who live in urban areas with a huge number of automobiles. The effect of the air pollution was detected in terms of emergency services and admittances in large and small cities in Brazil. Parker et al. [172], in a research conducted with North-American children, came to the same conclusion: the results provide evidence of adverse health effects for children living in areas with chronic exposure to higher levels of $\mathrm{O}_{3}$ and $\mathrm{PM}_{2.5}$ compared with children with lower exposures.

Another threat to the health of children thatcalled our attention was the environmental contamination due to agrochemicals. In the last few years, Brazil has become the number one consumer of agrochemicals in the world [173] and increasingly dependent of such products and chemical fertilizers. In that sense, that exposure to agrochemicals and pesticides increase the prevalence of morbimortality due to cancer in the infant-juvenile population, and is also a possible risk factor for adverse effects during pregnancy, such as acute leukemia, premature parturition and improper maturation $[125,126,128]$. Another perspective on this type of exposure is the study conducted by Rasier et al. [174] that reported exposure of the developing fetus or neonate to environmentally relevant concentrations of certain chemicals, among them endocrine disrupters, induces morphological, biochemical and/or physiological disorders in the brain and reproductive organs, by interfering with hormone actions. In our research, we did not find articles focusing this issue in the Brazilian children.

Conversely, exposure to environmental contaminants, including heavy metals, is a generalized problem relatively wellstudied in Brazil. The CDC [175] informs that today there are approximately half a million U.S. children ages 1-5 with blood lead levels above $5 \mu \mathrm{g} / \mathrm{dl}$, the reference level at which CDC recommends public health actions be initiated. In our review, lead showed morbidity when the levels in the blood were higher than $10 \mu \mathrm{g} / \mathrm{dl}$ [136] and could cause alterations in language acquisition [135].

We have also seen in the Amazon the presence of another toxic exposure agent, the mercury. When it transforms into methylmercury (MeHg) - its most toxic form - it can affect the neurological development of children that ingest contaminated fish during a prolonged period of time [137]. According to Bose-0'Reilly et al. [176], even though epidemiologic studies in many countries report that fish intake is the single most influential predictor of blood or hair mercury levels, fish is a good dietary source of lean protein and omega-3 fatty acids, which are important for children to develop properly. So, for the authors, these beneficial effects may obscure adverse effects of methylmercury exposure.

According to literature, seroepidemiological surveys are an important research tool, especially in Public Health, because they allow the determination of the infection coefficient for a given pathology in a given population [148]. In that sense, the subtheme "exposure to other biological agents" showed us the importance of epidemiological studies present in endemic regions in Brazil, where the socioeconomic conditions are worse, or by children activities in the forest around the houses. Studies on pediatric malaria are scarce [177] despite the increasing number of cases in children and adolescents due to malaria urbanization in various cities of the Amazon Region [152].

Concerning dengue fever, more than 2.5 billion people, in over 100 countries, are estimated to live in risk areas for the transmission of Aedes aegypty's vector [178]. Our data survey had only 4 (30\%) studies dedicated to the risk factors to children exposed to the dengue virus $[141,142,145,147]$. The researches were conducted in the same Brazilian areas where today there are more cases of the zika virus and chikungunya caused by Aedes aegpty [179].

Besides being considered an international public health emergency with its epicenter in Brazil [180], the strong association, in time and place, between infections with the zika virus and a rise in detected cases of congenital malformations and neurological complications in newborns [181, 182, 183] of pregnant women who had contact with the vector highlights the importance of $A$. aegypty control. In January 2016, the Brazilian Ministry of Health [179] confirmed these data by disclosing 
evidence that the zika virus crossed the placental barrier, transmitting the disease to the developing fetus [179]. Nowadays, the elimination of this vector is becoming a health emergency in countries around the world.

An effective prevention policy for exposure to biological agents to be successful should effectually involve academic community, public health sectors and the society as a whole.

\section{Conclusions}

The scenery for children life including adverse effects of danger exposures in home life, lack of sanitation and other socio-environmental factors with regional hazards can generate an unfavorable environment for their health in several parts of Brazil. Studies conducted in all regions of the country have shown that the occurrence of preventable diseases from domestic to regional threats and their determinants in childhood years occur not by chance or at random in any community. It is possible to establish causal relations and, thus, define the protective factors to be considered in order to improve the quality of life of Brazilian children. Poverty and the lack of access to information on inherent healthcare practices that benefit the children population are key factors that must be changed to prevent pediatric diseases.

Other aspects arise when discussing how to improve the health of children all over Brazil. Considering the extensive area of the country and regional peculiarities, there is a need for government actions such as enforcing a tighter control on the use of pesticides and agrochemicals in general, monitoring air quality according to health standards and educational effort on parents and guardians in keeping children far from medicine, medicine cabinets and the like, disposal of waste in a safe and appropriately way, and others. Nonetheless, what can be learned from the studies analyzed is that the public sector as well as legal guardians must work together to reduce the number of preventable infant diseases and deaths due to environmental hazards.

\section{References}

1. Bellamy C. Healthy environments for children. Bull World Health Organ. 2003;81(3):157-157. doi: 10.1590/S0042-96862003000300002.

2. World Health Organization. Global Health Observatory (GHO) data. Under-five mortality. WHO; Geneva. 2017.

3. United Nations Children's Fund. Levels and Trends in Child Mortality Report 2015. Estimates Developed by the United Nation Inter-agency Group for Child Mortality Estimation. UNICEF; USA,2015.

4. Prüss-Üstün A, Wolf J, Corvalán CF, Bos RV, Neira, MP. Preventing disease through healthy environments: a global assessment of the burden of disease from environmental risks. WHO; Geneva, 2016.

5. Ercumen A, Gruber JS. Colford Jr JM. Water Distribution System Deficiencies and Gastrointestinal Illness: A Systematic Review and Meta-Analysis. Environ Health Perspect. 2014;122(7):651-60. doi:10.1289/ehp.1306912.

6. United Nations Children's Fund. Committing to Child Survival: A Promise Renewed Progress Report. UNICEF; USA,2013. [cited 2014 Nov 14]. Available from: http://www.apromiserenewed.org/

\section{APR_2014_web_15Sept14.pdf.}

7. Edwards T M, Myers J P. Environmental exposures and gene regulation in disease etiology. Environ Health Perspect. 2007;115(9):12641270. doi: 10.1289 /ehp.9951.

8. Bucaretchi F, Baracat EC. Acute toxic exposure in children: an overview. J Pediatr. 2005;81:S212-222. doi: 10.1590/S002175572005000700012 .

9. Le Cann P, Bonvallot N, Glorennec P, Deguen S, Goeury C, et al. Indoor environment and children's health: recent developments in chemical, biological, physical and social aspects. Int J Hyg Environ Health. 2011;215(1):1-18. doi: 10.1016/j.ijheh.2011.07.008.

10.DiFranza JR,Aligne A, Weitzman M. Prenatal and Postnatal Environmental Tobacco Smoke Exposure and Children's Health. Pediatrics. 2004;113:1007-1015. doi: 10.1542/peds.113.4.S1.1007.

11. Currie J. Pollution and Infant Health. Child Development Perspectives. 2013;7(4): 237-242. doi: 10.1111/cdep.12047.

12. Chan-Yeung M, Dimich-Ward H. Respiratory health effects of exposure to environmental tobacco smoke. Respirology. 2003;8(2):131-9. doi:10.1046/j.1440-1843.2003.00453.x.

13. Hang B, Sarker AH, Havel C, Saha S, Hazra TK, et al. Third hand smoke causes DNA damage in human cells. Mutagenesis. 2013;1-11. doi:10.1093/mutage/get013.

14. World Health Organization. Household air pollution and health. Fact sheet N²92. WHO; Geneva, 2014a.

15. Bruce N, Perez-Padilla R, Albalak R. Indoor air pollution in developing countries: a major environmental and public health challenge. Bull World Health Organ. 2000;78(9):1078-1092. doi.org/10.1590/ S0042-96862000000900004.

16. Bruce N, Perez-Padilla R, Albalak R. The health effects of indoor air pollution exposure in developing countries. WHO; Geneva, 2002. [cited 2014 May 14]. Available from: http://whqlibdoc.who.int/ hq/2002/WHO_SDE_OEH_02.05.pdf.

17. World Health Organization. Humanitarian Health Action. Ambient (outdoor) air quality and health. Fact sheet n.313.WHO; Geneva, 2014. [cited 2014 Jul 13]. Available from: http://www.who.int/ mediacentre/factsheets/fs313/en/.

18. Landrigan PJ, Garg A. Chronic effects of toxic environmental exposures on children's health. J Toxicol Clin Toxicol. 2002;40(4):449-56. doi:10.1081/CLT-120006746PMID:12216997.

19. Turner MC, Wigle DT, Krewski D. Residential pesticides and childhood leukemia: a systematic review and meta-analysis. Environ Health Perspect. 2010;118(1):33-41. doi:10.1289/ehp.0900966.

20.World Health Organization. Water Safety in Distribution Systems - Public Health, Environmental and Social Determinants Water, Sanitation, Hygiene and Health. WHO; Geneva, Switzerland, 2014c. [cited 2014 Nov 16]. Available from: http://www.who.int/ water_sanitation_health/publications/Water_safety_distribution_ systems_2014v1.pdf.

21. Ostro B, Roth L, Malig B, Mart M. The effects of fine particle components on respiratory hospital admissions in children. Environ Health Perspect. 2009;117(3):475-480. doi:10.1289/ehp.11848.

22. Chaudhuri N, Fruchtengarten L. Where the child lives and plays: A Resource Manual for the Health Sector. In: Children's health and 
the environment: A Global Perspective (Pronczuk-GarbinoJ, ed.). WHO; Geneva, 2005. Chapter 3. p. 29-39. [cited 2014

May 10]. Available from: http://whqlibdoc.who.int/ publications/2005/9241562927_eng.pdf.

23. Landrigan PJ, Kimmel CA, Correa A, Eskenazi B. Where the child lives and plays: A Resource Manual for the Health Sector. In: Children's health and the environment: A Global Perspective (Pronczuk-GarbinoJ, ed.). Environ Health Perspect. 2004;112(2):257-65.

24. Institute of Geography and Statistic Brazil in figures. IBGE; Brazil 2014, 22:1-428. [cited 2015 Nov 23]. Available from: http://biblioteca.ibge. gov.br/index.php/biblioteca-catalogo?view=detalhes\&id=72.

25.United Nations Development Programme. Human Development Report. Sustaining Human Progress: Reducing Vulnerabilities and Building Resilience. UNDP; USA, 2014. [cited 2015 Apr 14]. Available from: http://www.pnud.org.br/arquivos/rdh2014. pdf.

26. Tavares EO, Buriola AA, Santos JAT, Ballani TSL, Oliveira MLF. Factors associated with poisoning in children. Esc. Anna Nery. 2013;17(1):3137. doi:10.1590/S1414-81452013000100005.

27. Lira SVG, Silva JG, Abreu RNDC, Moreira DP, Vieira LJES, Frota MA. Intoxications by pesticides in children, adolescents and youngsters in Fortaleza (CE). Cienc Cuid Saude. 2009;8(1):48-55. doi:10.4025/ cienccuidsaude.v8i1.7772.

28. Lessa MA, Bochner R. Analysis of hospitalizations of children under one year of age due to drug intoxication and adverse events in Brazil. Rev. bras. epidemiol. 2008; 11(4):660-667. Doi:10.1590/S1415$790 \times 2008000400013$.

29. Lourenço J, Furtado BMA, Bonfim C. Exogenic poisoning in children assisted in a pediatric emergency unit. Acta paul. enferm. 2008;21(2):282-6. doi:10.1590/S0103-21002008000200008.

30.Siqueira KM, Janaína Brandão R, Lima HF, Garcia ACAG, Gratone FM, et al. Profile of the infantile exogenous intoxications assisted in a specialized hospital of Goiânia-GO. Rev. Eletr. Enf. 2008; 10 (3): 66272. [cited 2014 Feb 13]. Available at: http://www.fen.ufg.br/revista/ v10/n3/v10n3a12.htm.

31. Martins CBG, Andrade SM, Paiva PAB. Accidental poisoning among children and adolescents in a county in southern Brazil. Cad. Saude Publica. 2006;22(2):407-414. doi:10.1590/S0102311X2006000200018.

32. Ramos CLJ, Targa MBM, Stein AT. Caseload of poisoning among children treated by the Rio Grande do Sul State Toxicology Information Center (CIT/RS), Brazil. Cad Saude Publica. 2005;21(4):1134-1141. doi:10.1590/S0102-311X2005000400015.

33. Bucaretchi F, Dragosavac S, Vieira RJ. Acute exposure to imidazoline derivatives in children. J Pediatr. 2003;79(6):519-24. doi:10.1590/ S0021-75572003000600010.

34. Matos GC, Rozenfeld S, Bortoletto ME. Drug intoxication among children under five years old. Rev. Bras. Saude Mater. Infant. 2002;2(2):167-176. doi: 10.1590/S1519-38292002000200009.

35. Schvartsman C, Farhat SCL, Schvartsman, SPHN. Parental smoking patterns and their association with wheezing in children. Clinics. 2013;68(7):934-939. doi:10.6061/clinics/2013(07)08.

36. Coelho AS, Rocha AS, Jong LC. Outcomes of secondhand smoking in children. Cienc Cuid Saude. 2012; 11 (2): 294-301. doi: 10.4025/ cienccuidsaude.v11i2.10281.

37.Zhang L, González-Chica DA, Cesar JA , Mendoza-Sassi RA, Beskow $B$, et al. Maternal smoking during pregnancy and anthropometric measurements of newborns: a population-based study in southern of Brazil. Cad. Saude Publica. 2011;27(9):1768-1776. doi:10.1590/ S0102-311X2011000900010.

38. Prietsch SOM, Fischer GB, César JA, Berenice SL, Luciano VB Jr, et al. Acute lower respiratory illness in under-five children in Rio Grande, Rio Grande do Sul State, Brazil: prevalence and risk factors. Cad. Saude Publica. 2008;24(6):1429-1438. doi:10.1590/S0102$311 \times 2008000600023$.

39. Casagrande RRD, Pastorino AC, Souza RGL, Leone C, Solé D, et al. Asthma prevalence and risk factors in schoolchildren of the city of São Paulo, Brazil. Rev. Saude Publica. 2008;42(3):517-523. doi: 10.1590/ S0034-89102008000300018.

40. Macedo SEC, Menezes AMB, Elaine Albernaz E, Paulo Post P, Knorst M. Risk factors for acute respiratory disease hospitalization in children under one year of age. Rev. Saude Publica. 2007;41(3):351-358. doi: 10.1590/S0034-89102007000300005.

41. Prietsch SOM, Fischer GB, César JA, Cervo PV, Sangaletti LL, et al. Risk factors for recurrent wheezing in children under 13 years old in the South of Brazil. Rev Panam Salud Publica. 2006;20(5):331-337. doi:10.1590/S1020-49892006001000006.

42. Gonçalves-Silva RMV, Valente JG, Lemos-Santos MGF, Sichieri R. Household smoking and respiratory disease in under-five children. Cad. Saude Publica. 2006;22(3):579-586. doi:10.1590/S0102$311 \times 2006000300013$.

43. Gonçalves-Silva RMV, Valente JG, Lemos-Santos MGF, Sichieri R. Household smoking and stunting for children under five years. Cad. Saude Publica. 2005;21(5):1540-1549. doi:10.1590/S0102$311 X 2005000500027$.

44. Chatkin MN, Menezes AMB. Prevalence and risk factors for asthma in schoolchildren in southern Brazil. J Pediatr. 2005;81(5):411-416. doi:10.2223/JPED.1393.

45. Carvalho LMT, Pereira EDBP. Respiratory morbidity among passive smoking children. J Pneumologia. 2002;28(1):8-14. doi:10.1590/ S0102-35862002000100004.

46. Prietsch SOM, Fischer GB, César JA, Alisson RF, Halid Mehanna, et al. Acute disease of the lower airways in children under five years of age: role of domestic environment and maternal cigarette smoking. JPediatr. 2002;78(5):415-422. doi:10.1590/S0021-75572002000500013.

47. Pereira EDB, Torres L, Macêdo J, Medeiros MMC. Effects of environmental tobacco smoke on lower respiratory system of children under 5 years old. Rev. Saude Publica. 2000;34(1):39-43. doi :10.1590/ S0034-89102000000100008.

48. Torres RMC, Bittencourt AS, Oliveira RM, Siqueira ASP, Sabroza PC, et al. Use of local level indicators for the spatial analysis of morbidity due to diarrhea and its relation with lifestyle conditions. Cienc. saude coletiva. 2013;18(5):1441-1450. doi:10.1590/S141381232013000500029 .

49. Mendes PSA, Ribeiro Jr HC, Mendes CMC. Temporal trends of overall mortality and hospital morbidity due to diarrheal disease in Brazilian children younger than 5 years from 2000 to 2010. J Pediatr.2013;89(3):315-325. Doi:10.1016/j.jped.2012.10.002. 
50. Paz MGA, Almeida MF, Günther WMR. Diarrhea in children and sanitation and housing conditions in periurban areas in the city of Guarulhos, SP. Rev. bras. epidemiol. 2012;15(1):188-197. Doi:10.1590/ S1415-790X2012000100017.

51. Ciaccia MCC, Moreira RC, Ferraro AA, Lemos MF, Oba IT, et al. Epidemiological and serological aspects of hepatitis A among children and teenagers in the city of Santos: a cross-sectional study. São Paulo Med. J. 2012;130(4):230-235. doi:10.1590/S151631802012000400005.

52. Markus JR, Cruz CR, Maluf EMCP, Tahan TT, Murilo MH. Seroprevalence of Hepatitis A in children and adolescents. J Pediatr. 2011;87(5):419424. doi:10.1590/S0021-75572011000500009.

53. Bellido JG, Barcellos C, Barbosa FS, Bastos FI. Environmental sanitation and mortality associated with waterborne diseases in children under 5 years of age in Brazil. Rev Panam Salud Publica. 2010;28(2):114120. doi:10.1590/S1020-49892010000800007.

54. Melli LCFL, Waldman EA. Temporal trends and inequality in under-5 mortality from diarrhea. J Pediatr. 2009;85(1):21-27. doi:10.2223/ JPED.1856.

55. Cesar JA, Chrestani MAD, Fantinel EJ, Gonçalves TS, Neumann NA. Child health in poor areas: findings from a population-based study in Caracol, Piauí, and Garrafão do Norte, Pará, Brazil. Cad. Saude Publica. 2009;25(4):809-818. Doi:10.1590/S0102-311X2009000400012.

56. Genser B, Strina A, Santos LA, Teles CA, Prado MS, et al. Impact of a city-wide sanitation intervention in a large urban centre on social, environmental and behavioural determinants of childhood diarrhoea: analysis of two cohort studies. Int J Epidemiol. 2008;37(4):831-440. doi:10.1093/ije/dyn101.

57. Melo MC, Taddei JA, Diniz-Santos DR, Vieira C, Carneiro NB, et al. Incidence of diarrhea in children living in urban slums in Salvador, Brazil. Braz J Infect Dis. 2008;12(1):89-93. doi:10.1590/S141386702008000100019 .

58. Vasconcelos MJOB, Batista Filho M. Diarrheal disease in children under five years of age in the State of Pernambuco, Brazil: prevalence and utilization of health services. Rev. bras. epidemiol. 2008;11(1):128138. doi:10.1590/S1415-790X2008000100012.

59. Barreto ML, Genser B, Strina A, Maria Gloria Teixeira, Ana Marlucia 0 Assis, et al. Effect of city-wide sanitation programme on reduction in rate of childhood diarrhoea in northeast Brazil: assessment by two cohort studies. Lancet. 2007;370(9599):1622-1628. Doi: 10.1016/ S0140-6736(07)61638-9.

60. Teixeira JC, Heller L. Childhood diarrhea-related to environmental factors in subnormal settlements in Juiz de Fora, Minas Gerais. Rev. Bras. Saude Mater. Infant. 2005;5(4):449-455. doi:10.1590/S151938292005000400008.

61.Zago-Gomes MP, Stantolin GC, Perazzio S, Aikawa KH, Gonçalves CS, et al. Prevalence of anti-hepatits A antibodies in children of different socioeconomic conditions in Vila Velha, ES. Rev. Soc. Bras. Med. Trop. 2005;38(4):285-289. doi:10.1590/S0037-86822005000400001.

62. Teixeira JC, Heller L. Environmental factors related to child malnutrition in slums, Juiz de Fora, MG. Rev. bras. epidemiol. 2004;7(3):270-278. doi:10.1590/S1415-790X2004000300005.

63. Vanderlei LCM, Silva GAP, Braga JU. Risk factors for hospitalization due to acute diarrhea in children under two years old: a case-control study. Cad. Saude Publica. 2003;19(2):455-463. doi:10.1590/S0102-

\section{$311 X 2003000200012$.}

64. Strina A, Cairncross S, Barreto ML, Larrea C, Prado MS. Childhood diarrhea and observed hygiene behavior in Salvador, Brazil. Am J Epidemiol. 2003;157(11):1032-1038. doi: 10.1093/aje/kwg075.

65.Schnack FJ, Fontana LM, Barbosa PR, Silva LS, Baillargeon CM, et al. Enteropathogens associated with diarrheal disease in infants $(<5$ years old) in a population sample in Greater Metropolitan Criciúma, Santa Catarina State, Brazil. Cad. Saude Publica. 2003;19(4):12051208. doi: 10.1590/S0102-311X2003000400042.

66. Medronho RA, Ortiz Valencia LI, Fortes BPMD, Braga RCC, Ribeiro SV. Spatial analysis of hepatitis A seroprevalence in children of a poor region of Duque de Caxias, Rio de Janeiro, Brazil. Rev. bras. epidemiol. 2003;6(4):328-334. doi:10.1590/S1415-790X2003000400007.

67. Assis SB, Souto FJD, Fontes CJF, Gaspar AMC. Prevalence of hepatitis A and $E$ virus infection in school children of an Amazonian municipality in Mato Grosso State. Rev. Soc. Bras. Med. Trop. 2002;35(2):155-158. doi:10.1590/S0037-86822002000200005.

68. Benicio MHD'A, Monteiro CA. Secular trends in child diarrhea in S. Paulo city, Brazil (1984-1996). Rev. Saude Publica. 2000;34(6):83-90. Doi:10.1590/S0034-89102000000700011.

69. Catapreta CAA, Heller L. Association between household solid waste collection and health. Rev Panam Salud Publica. 1999;5(2):88-96. doi:10.1590/S1020-49891999000200003.

70. Belo VS, Oliveira RB, Fernandes PC, Bruno Warlley L. Birth, Fábio Vitorino Fernandes, et al. Factors associated with intestinal parasitosis in a population of children and adolescents. Rev. paul. Pediatr. 2012;30(2):195-201. doi:10.1590/S0103-05822012000200007.

71. Araujo Filho HB, Carmo-Rodrigues MS, Mello CS, Melli LCFL, Tahan $\mathrm{S}$, et al. Intestinal parasitoses are associated with lower values of weight and height in school-aged children from low socioeconomic level. Rev. paul. Pediatr. 2011;29(4):521-528. doi:10.1590/S010305822011000400009.

72. Silva JC, Furtado LFV, Ferro TC, Bezerra KC, Borges EP, et al. Parasitism due to Ascaris lumbricoides and its epidemiological characteristics among children in the State of Maranhão. Rev. Soc. Bras. Med. Trop. 2011;44(1):100-102. Doi: 10.1590/S0037-86822011000100022.

73. Barreto ML, Genser B, Strina A, Teixeira MG, Assis AM, et al. Impact of a Citywide Sanitation Program in Northeast Brazil on Intestinal Parasites Infection in Young Children. Environ Health Perspect. 2010;118:1637-1642. doi:10.1289/ehp.1002058.

74. Fonseca EOL, Teixeira MG, Barreto ML, Carmo EH, Costa MCN. Prevalence and factors associated with geohelminth infections in children living in municipalities with low HDI in North and Northeast Brazil. Cad. Saude Publica. 2010;26(1):143-152. doi:10.1590/S0102311X2010000100015.

75. Basso RMC, Silva-Ribeiro RT, Soligo DS, Ribacki SI, Callegari-Jacques $\mathrm{SM}$, et al. Evolutions of the prevalence of intestinal parasitosis among school children in Caxias do Sul, RS. Rev. Soc. Bras. Med. Trop. 2008;41(3):263-268. doi:10.1590/S0037-86822008000300008.

76. Matos SMA, Assis AMO, Prado MA, Strina A, Santos LA, et al. Giardia duodenalis infection and anthropometric status in preschoolers in Salvador, Bahia State, Brazil. Cad. Saude Publica. 2008;24(7):15271535. doi:10.1590/S0102-311X2008000700007.

77. Araújo NS, Rodrigues CT, Cury MC. Helminthes in sandboxes of day 
care centers of a city in southeastern Brazil. Rev Saude Publica. 2008;42(1):150-153. doi: 10.1590/S0034-89102008000100021.

78. Moraes LRS. Household solid waste bagging and collection and their health implications for children living in outlying urban settlements in Salvador, Bahia State, Brazil. Cad. Saude Publica. 2007;23(4):S643-S649. doi:10.1590/S0102-311X2007001600024.

79. Pereira MGC, Atwill ER, Barbosa AP. Prevalence and associated risk factors for Giardia lamblia infection among children hospitalized for diarrhea in Goiânia, Goiás State, Brazil. Rev. Inst. Med. trop. São Paulo. 2007;49(3):139-145. Doi: 10.1590/S0036-46652007000300002.

80. Buschini MLT, Pittner E, Czervinski T, et al. Spatial distribution of enteroparasites among school children from Guarapuava, State of Paraná, Brazil. Rev. bras. epidemiol. 2007; 10 (4): 568-578. doi: 10.1590/S1415-790X2007000400015.

81. Mascarini LM, Donalísio-Cordeiro MR. Epidemiological aspects of enteroparasitosis at daycare centers in the city of Botucatu, State of São Paulo, Brazil. Rev. bras. epidemiol. 2006a;9(3):297-308. doi: 10.1590/S1415-790X2006000300004.

82. Mascarini LM, Donalísio-Cordeiro MR. Giardiasis and cryptosporidiosis in children institutionalized at daycare centers in the state of São Paulo. Rev. Soc. Bras. Med. Trop. 2006b;39(6):577-579. doi: 10.1590/ S0037-86822006000600015.

83. Carvalho TB, Carvalho LR, Mascarini LM. Occurrence of enteroparasites in day care centers in Botucatu (São Paulo State, Brazil) with emphasis on Cryptosporidium sp., Giardia duodenalis and Enterobius vermicularis. Rev. Inst. Med. trop. S. Paulo. 2006;48(5):269273. doi:10.1590/S0036-46652006000500006.

84. Gurgel RQ, Cardoso GS, Silva AM, Santos LN, Oliveira RCV. Children day care center: exposition or protection environment to intestinal parasites infestation in Aracaju, SE. Rev. Soc. Bras. Med. Trop. 2005;38(3):267-269. Doi: 10.1590/S0037-86822005000300014.

85.Teixeira JC, Heller L. Environmental factors related to intestinal helminth infections in subnormal settled areas, Juiz de Fora, MG. Eng. Sanit. Ambient. 2004b;9(4):301-305. doi:10.1590/S141341522004000400006.

86. Quadros RM, Marques S, Arruda AAR, Delfes PSWR, Medeiros IAA. Intestinal parasites in nursey schools of Lages, southern Brazil. Rev. Soc. Bras. Med. Trop. 2004;37(5):422-423. doi: 10.1590/S003786822004000500012.

87. Ferreira P, Lima MR, Oliveira FB, Maria LMP, Leila BMR, et al. Occurrence of intestinal parasites and commensal organisms among schoolchildren living in a 'landless farm workers' settlement in Campo Florido, Minas Gerais, State Brazil. Rev. Soc. Bras. Med. Trop. 2003;36(1):109-111. doi:10.1590/S0037-86822003000100015.

88. Carneiro FF, Cifuentes E, Tellez-Rojo MM, Romieu I. The risk of Ascaris lumbricoides infection in children as an environmental health indicator to guide preventive activities in Caparaó and Alto Caparaó, Brazil. Bull World Health Organ. 2002;80(1):40-46. doi:10.1590/ S0042-96862002000100008.

89. Carvalho OS, Guerra HL, Campos YR, Caldeira RL, Massara CL. Prevalence of intestinal helminths in three regions of Minas Gerais State. Rev. Soc. Bras. Med. Trop. 2002;35(6):597-600. doi:10.1590/ S0037-86822002000600009.

90. Prado MS, Barreto ML, Strina A, Faria JÁ, Nobre AA, et al. Prevalence and intensity of infection by intestinal parasites in school-aged children in the City of Salvador (Bahia, Brazil). Rev. Soc. Bras. Med. Trop. 2001;34(1):99-101. doi:10.1590/S0037-86822001000100016.

91. Ferreira UM, Ferreira CS, Monteiro CA. Secular trends in child intestinal parasitic diseases in S. Paulo city, Brazil (1984-1996). Rev. Saude Publica. 2000;34(6):73-82. doi: 10.1590/S003489102000000700010.

92. Rocha RS, Silva JG, Peixoto SV, et al. Evaluation of the schistosomiasis and others intestinal parasitosis in the school children of Bambuí county, Minas Gerais, Brazil. Rev. Soc. Bras. Med. Trop. 2000;33(5):431436. doi:10.1590/S0037-86822000000500004.

93. Tsuyuoka R, Bailey JW, Guimarães AMd'NA, Gurgel RQ, Cuevas LE. Anemia and intestinal parasitic infections in primary school students in Aracaju, Sergipe, Brazil. Cad. Saude Publica. 1999;15(2):413-421. doi:10.1590/S0102-311X1999000200026.

94.Saldiva SR, Silveira AS, Philippi ST, Torres DM, Mangini AC, et al. Ascaris-Trichuris association and malnutrition in Brazilian children. Paediatr Perinat Epidemiol. 1999;13(1):89-98. doi:10.1046/j.13653016.1999.00145.x.

95. Machado RC, Marcari EL, Cristante SFV, Carrareto CMA. Giardiasis and helminthiasis in children of both public and private day-care centers and junior and high schools in the city of Mirassol, São Paulo State, Brazil. Rev. Soc. Bras. Med. Trop. 1999;32(6):697-704. doi:10.1590/ S0037-86821999000600013.

96. Coelho LMPS, Aidar Sobrinho T, Oliveira SM, Marcelo TI, Alexandre MY, Allyson YKN, et al. Helminth eggs and larvs in the water closet of some city nursery schools (Infant Educational Center) from Sorocaba, SP, Brazil, and their frequency in children feces. Rev. Soc. Bras. Med. Trop. 1999;32(6):647-652. doi:10.1590/S0037-86821999000600006.

97. Andrade Filho VS, Artaxo P, Hacon S, Carmo CN, Cirino G. Aerosols from biomass burning and respiratory diseases in children, Manaus, Northern Brazil. Rev Saude Publica. 2013;47(2):239-247. doi:10.1590/S0034-8910.2013047004011.

98. Romão R, Pereira LAA, Saldiva PHN, Pinheiro PM, Braga ALF, et al.The relationship between low birth weight and exposure to inhalable particulate matter. Cad. Saude Publica. 2013;29 (6):1101-1108. doi:10.1590/S0102-311X2013000600007.

99. Vieira SE, Stein RT, Ferraro AA, Pastro LD, Pedro SS, et al. Urban air pollutants are significant risk factors for asthma and pneumonia in children: the influence of location on the measurement of pollutants. Arch Bronconeumol. 2012;48(11):389-95. doi:10.1016/j. arbres.2012.05.005.

100.Jasinski R, Pereira LAA, Braga ALF. Air pollution and pediatric hospital admissions due to respiratory diseases in Cubatão, São Paulo State, Brazil, from 1997 to 2004. Cad. Saúde Pública. 2011;27(11):22422252. doi:10.1590/S0102-311X2011001100017.

101.Riguera D, André PA, Zanetta DMT. Sugar cane burning pollution and respiratory symptoms in school children in Monte Aprazível, Southeastern Brazil. Rev. Saude Publica. 2011;45(5):878-886. doi:10.1590/S0034-89102011005000052.

102.Natali RMT, Santos DSPS, Fonseca AMC, Giulia Claudia de MF, Ana Helena AF, et al. Hospital admissions due to respiratory diseases in children and adolescents of São Paulo city, 2000-2004. Rev. paul.pediatr. 2011;29(4):584-590. doi:10.1590/S0103-05822011000400018.

103.Moraes ACL, Ignotti E, Netto PA, Jacobson LSV,Castro H, et al. Wheezing in children and adolescentes living next to a petrochemical 
plant in Rio Grande do Norte, Brazil. J Pediatr. 2010;86(4):337-344. doi:10.1590/S0021-75572010000400015.

104.Barreto ICHC, Grisi SJFE. Self-reported morbidity and its conditioning factors in children aged 5 to 9 in the city of Sobral, Brazil. Rev. bras. epidemiol. 2010;13(1):35-48. doi:0.1590/S1415$790 \times 2010000100004$.

105.Moura M, Junger WL, Mendonça GA, Ponce de Leon A. Air quality and emergency pediatric care for symptoms of bronchial obstruction categorized by age bracket in Rio de Janeiro, Brazil. Cad. Saude Publica. 2009;25(3):635-644. doi:10.1590/S0102-311X2009000300018.

106.Castro HA, Cunha MF, Mendonça GAS, Junger WL, Cunha-Cruz J, et al. Effect of air pollution on lung function in schoolchildren in Rio de Janeiro, Brazil. Rev. Saúde Publica. 2009;43(1):26-34. doi:10.1590/ S0034-89102009000100004.

107.Nascimento LFC, Moreira DA. Are environmental pollutants risk factors for low birth weight? Cad. Saude Publica. 2009;25(8):17911796. doi:10.1590/S0102-311X2009000800015.

108.Medeiros A, Gouveia N, Machado RPP, Miriam Regina de S, Gizelton PA, et al. Traffic-Related Air Pollution and Perinatal Mortality: A Case-Control Study. Environ Health Perspect. 2009;117(1):127-132. doi:10.1289/ehp.11679.

109.Rosa AM, Ignotti E, Hacon SS, Castro HA. Analysis of hospitalizations for respiratory diseases in Tangará da Serra, Brazil. J bras pneumol. 2008;34(8):575-582. doi:10.1590/S1806-37132008000800006.

110.Rosa AM, Ignotti E, Botelho C,Castro HA, Hacon SS. Respiratory disease and climatic seasonality in children under 15 years old in a town in the Brazilian Amazon. J Pediatr. 2008b;84(6):543-549. doi:10.1590/S0021-75572008000700012.

111.Castro HA, Hacon S, Argento R, Washington LJ, Carla De FM, et al. Air pollution and respiratory diseases in the Municipality of Vitória, Espírito Santo State, Brazil. Cad. Saude Publica. 2007;23(4):S630-S642. doi:10.1590/S0102-311X2007001600023.

112.Junger WL, Ponce de Leon A. Air pollution and low birth weight in the city of Rio de Janeiro, Brazil, 2002. Cad. Saude Publica. 2002;23(4):S588-S598. doi:10.1590/S0102-311X2007001600019.

113.Nascimento LFC, Pereira LAA, Braga ALF, Módolo MCC, Carvalho Jr JA. Effects of air pollution on children's health in a city in Southeastern Brazil. Rev. Saude Pública. 2006;40(1):77-82. doi: 10.1590/S003489102006000100013.

114.Farhat SCL, Paulo RLP, Shimoda TM, Conceição GMS, Lin CA, et al. Effect of air pollution on pediatric respiratory emergency room visits and hospital admission. Braz J Med Biol Res. 2005;38(2):227-35. Doi:10.1590/S0100-879X2005000200011.

115.Saldanha CT, Silva AMC, Botelho C. Climate variations and health services use for the treatment of asthmatic children under five years of age: an ecological study. J.bras. pneumol. 2005;31(6):492-498. Doi: 10.1590/S1806-37132005000600006.

116. Medeiros A, Gouveia N. Relationship between low birthweight and air pollution in the city of Sao Paulo, Brazil. Rev. Saude Publica. 2005;39(6):965-972. doi:10.1590/S0034-89102005000600015.

117.Nascimento LFC, Módolo MCC, Carvalho Jr. JA. Atmospheric pollution effects on childhood health: an environmental study in the Paraíba Valley. Rev. Bras. Saude Mater. Infant. 2004;4(4):367-374. Doi: 10.1590/S1519-38292004000400005.
118.Gouveia N, Bremner S, Novaes H. Association between ambient air pollution and birth weight in São Paulo, Brazil. J Epidemiol Community Health. 2004;58(1):11-17. doi: 10.1136/jech.58.1.11.

119.Bakonyi SMC, Danni-Oliveira IM, Martins LC, Braga ALF. Air pollution and respiratory diseases among children in Brazil. Rev Saude Publica. 200;38(5):695-700. doi:10.1590/S0034-89102004000500012.

${ }^{1}$ 120.Botelho C, Correia AL, Silva AMC, Macedo AG, Silva COS. Environmental factors and hospitalization of under-five children with acute respiratory infection. Cad. Saude Publica, 2003;19(6):17711780. doi: 10.1590/S0102-311X2003000600021.

121.Conceição GMC, Miraglia SGEK, Kishi HS, Saldiva PHN, Singer JM. Air Pollution and Child Mortality: A Time-Series Study in São Paulo, Brazil. Environ Health Perspect. 2001;109 (3):347-350.

122.Braga AL, Saldiva PHN, Pereira LA, Menezes JJ, Conceição GM, et al. Health effects of air pollution exposure on children and adolescents in São Paulo, Brazil. Pediatr Pulmonol. 2001;31(2):106-13.

123.Gouveia N, Fletcher T. Respiratory diseases in children and outdoor air pollution in São Paulo, Brazil: a time series analysis. Occup Environ Med. 2000;57(7):477-483. doi: 10.1136/oem.57.7.477.

124.Lin CA, Martins MA, Farhat SC, Pope CA 3rd, Conceição GM, et al. Air pollution and respiratory illness of children in São Paulo, Brazil. Paediatr Perinat Epidemiol. 1999;13(4):475-488. doi:10.1046/ j.1365-3016.1999.00210.x.

125.Curvo HRM, Pignati WA, Pignatti MG. Morbidity and mortality from cancer children and adolescents associated with the agricultural use of pesticides in the state of Mato Grosso, Brazil. Cad. Saude Coletiva. 2013;21(1):10-17. doi:10.1590/S1414-462X2013000100003.

126.Ferreira JD, Couto AC, Pombo-de-Oliveira MS, Koifman S, Brazilian Collaborative Study Group of Infant Acute Leukemia. In utero pesticide exposure and leukemia in Brazilian children $<2$ years of age. Environ Health Perspect. 2013;121(2):269-75. doi: 10.1289/ehp.1103942.

127.Dutra MDS, Jesus IM, Santos EC, Lima Mde O, Medeiros RL, et al. Longitudinal assessment of mercury exposure in schoolchildren in an urban area of the Brazilian Amazon. Cad. Saude Publica. 2012;28(8):1539-1545. Doi: 10.1590/S0102-311X2012000800012.

128.Cremonese C, Freire C, Meyer A, Koifman S. Pesticide exposure and adverse pregnancy events, Southern Brazil, 1996-2000. Cad. Saude Publica. 2012;28(7):1263-1272. doi: 10.1590/S0102$311 \times 2012000700005$.

129.Ferron MM, Lima AK, Saldiva PHN, Gouveia N. Environmental lead poisoning among children in Porto Alegre state, Southern Brazil. Rev. Saude Public. 2012;46(2):226-233. doi:10.1590/S003489102012000200004.

130.Sakuma AM, Capitani EM, Figueiredo BR, Maio FD, Paoliello MM, et al. Arsenic exposure assessment of children living in a lead mining area in Southeastern Brazil. Cad. Saude Publica. 2010;26(2):391-398. doi:10.1590/S0102-311X2010000200018.

131.Olympio KPK, Naozuka J, Oliveira PV, Cardoso MRA, Bechara EJH, et al. Association of dental enamel lead levels with risk factors for environmental exposure. Rev. Saude Publica, 2010;44(5):851-858. doi: 10.1590/S0034-89102010000500010.

132.Mattos RC, Carvalho MA, Mainenti HR, Xavier Junior EC, Sarcinelli Pde N, et al. Evaluation of risk factors related to lead exposure in 
children and adolescents from Rio de Janeiro. Cienc. saude coletiva. 2009;14(6):2039-2048. doi:10.1590/S1413-81232009000600011.

133.Farias LA, Santos NR, Favaro DIT, Braga ES. Total hair mercury in children from a coastal population in Cananéia, São Paulo State, Brazil. Cad. Saude Publica. 2008;24(10):2249-2256. doi: 10.1590/S0102$311 \mathrm{X} 2008001000006$.

134.Santos EO, Jesus IM, Câmara VM, Edílson da SB, Maria Izabel de J, et al. Correlation between blood mercury levels in mothers and newborns in Itaituba, Pará State, Brazil. Cad. Saude Publica. 2007;23(4):S622-S629. doi:10.1590/S0102-311X2007001600022.

135.Rodrigues OMPR, Carnier LE. Avaliação do Desenvolvimento Geral de Crianças de um a Cinco Anos de Idade Contaminadas por Chumbo. Interação em Psicologia. 2007;11(2):269-279.

136.Padula N, Abreu AMR, Miyazaki MH, Yoshinori LC, Tomita NE. Lead poisoning and child health: integrated efforts to combat this problem. Cad. Saude Publica. 2006;22(1):163-171. doi:10.1590/S0102311X2006000100017.

137.Tavares LMB, Câmara VM, Malm O, Santos ECO. Performance on neurological development tests by riverine children with moderate mercury exposure in Amazonia, Brazil. Cad. Saude Publica. 2005;21(4):1160-1167. doi:10.1590/S0102-311X2005000400018.

138.Carvalho FM, Silvany Neto AM, Tavares TM, Costa ACA, Chaves Cd'ElR, et al. Blood lead levels in children and environmental legacy of a lead foundry in Brazil. Rev Panam Salud. 2003;13(1):19-23. doi:10.1590/ S1020-49892003000100003.

139.Grandjean P, White RF, Nielsen A, Cleary D, Santos ECO. Methylmercury neurotoxicity in Amazonian children downstream from gold mining. Environ Health Perspect. 1999;107(7):587-589.

140.Cruz VM, Alencar NH, Medina C, Volkmer-Ribeiro VL, Gatta S, et al. Dangerous waters: outbreak of eye lesions caused by fresh water sponge spicules. Eye. 2013;27:398-402. doi:10.1038/eye.2012.290.

141.Costa CA, Façanha GP. Dengue virus serotypes in children of Manaus, State of Amazonas, 2008. Rev. Soc. Bras. Med. Trop. 2011;44(2):249251. doi: 10.1590/S0037-86822011000200024.

142.Rocha LA, Tauil PL. Dengue in children: clinical and epidemiological characteristics, Manaus, State of Amazonas, 2006 and 2007. Rev. Soc. Bras. Med. Trop. 2009;42(1):18-22. doi:10.1590/S003786822009000100005 .

143.Guerra JAO, Barbosa MGV, Loureiro ACSP, Coelho CP, Rosa GG, et al. American tegumentary leishmaniasis in children: epidemiological aspects of cases treated in Manaus, Amazonas, Brazil. Cad. Saude Publica. 2007;23(9):2215-2223. doi:10.1590/S0102$311 \times 2007000900029$.

144.Volkmer-Ribeiro C, Lenzi HL, Oréfice F, Pelajo-Machado M, de Alencar LM, et al. Freshwater sponge spicules: a new agent of ocular pathology. Mem. Inst. Oswaldo Cruz. 2006;101(8):899-903. doi: 10.1590/S007402762006000800013.

145.Campagna DS, Miagostovich MP, Siqueira MM, Cunha RV. Etiology of exanthema in children in a dengue endemic area. J Pediatr. 2006;82(5):354-358. doi:10.2223/JPED.1522.

146.Ampuero J, Urdaneta M, Macêdo VO. Risk factors for cutaneous shmaniasis transmission in children aged 0 to 5 years in an endemic area of Leishmania (Viannia) braziliensis. Cad. Saude Publica. 2005;21(1):161-170. doi:10.1590/S0102-311X2005000100018.
147.Rodrigues MBP, Freire HBM, Corrêa PRL, Mendonça ML, Silva MRI, et al. Is it possible to identify dengue in children on the basis of Ministry of Health criteria for suspected dengue cases? J Pediatr. 2005;81(3):209215. doi:10.2223/1341.

148.Coelho LMPS, Silva MV, Dini CY, Giacon NAA, Novo NF, et al. Human toxocariasis: a seroepidemiological survey in schoolchildren of Sorocaba, Brazil. Mem. Inst. Oswaldo Cruz. 200;99(6):533-557. doi:10.1590/S0074-02762004000600002.

149.Bucaretchi F, Herrera SRF, Hyslop S, Baracat ECE, Vieira RJ. Snakebites by Crotalus durissus ssp in children in Campinas, São Paulo, Brazil. Rev. Inst. Med. trop. S. Paulo. 2002;44(3):133-138. doi: 10.1590/S003646652002000300004 .

150.Bucaretchi F, Herrera SRF, Hyslop S, Baracat ECE, Vieira RJ. Snakebites by Bothrops spp in children in Campinas, São Paulo, Brazil. Rev. Inst. Med. trop. S. Paulo. 2001;43(6):329-333. doi: 10.1590/S003646652001000600006 .

151.Noronha E, Alecrim MGC, Romero GAS, Macêdo V. Clinical study of falciparum malaria in children in Manaus, AM, Brazil. Rev. Soc. Bras. Med. Trop. 2000;33(2):185-190. doi:10.1590/S003786822000000200005 .

152.Ventura AMRS, Pinto AYN, Silva RSU, Calvosa VSP, Silva Filho $\mathrm{MG}$, et al. Plasmodium vivax malaria in children and adolescents - epidemiological, clinical and laboratory features. J Pediatr. 1999;75(3):187-194.

153.Mowry JB, Spyker DA, Cantilena Jr LR, Bailey JE, Ford M. 2012 Annual Report of the American Association of Poison Control Centers' National Poison Data System (NPDS): 30th Annual Report. Clinical Toxicology. 2013;51:949-1229. doi:10.3109/15563650.2013.863906.

154.Salihu HM, Wilson RE. Epidemiology of prenatal smoking and perinatal outcomes. Early Hum Dev. 2007;83(11):713-720. doi:10.1016/j.earlhumdev.2007.08.002.

155.Öberg M, Jaakkola MS, Woodward A, Peruga A, Prüss-Ustün A. Worldwide burden of disease from exposure to second-hand smoke: a retrospective analysis of data from 192 countries. Lancet. 2011;377:139-146. doi:10.1016/S0140-6736(10)61388-8.

156.Gupta D, Aggarwal AN, Jindal SK. Pulmonary effects of passive smoking: the Indian experience. Tob Induc Dis. 2002;1(2):129-136. doi: 10.1186/1617-9625-1-2-129.

157.Heinrich J. Influence of indoor factors in dwellings on the development of childhood asthma. Int J Hyg Environ Health. 201;214(1):1-25. doi: 10.1016/j.ijheh.2010.08.009.

158.Matt GE, Quintana PJ, Zakarian JM, Fortmann AL, Chatfield DA, et al. When smokers move out and non-smokers move in: residential thirdhand smoke pollution and exposure. Tob Control. 2011;20(1):e1. doi: 10.1136/tc.2010.037382.

159.Ramírez N, Özel MZ, Lewis AC, Marcé RM, Borrull F, et al. Exposure to nitrosamines in thirdhand tobacco smoke increases cancer risk in non-smokers. Environ Int. 2014;71:139-147. doi: 10.1016/j. envint.2014.06.012.

160.Tolmasquim MT, Guerreiro A. Eficiência energética na indústria e nas residências no horizonte decenal (2010-2019). Ministério das Minas e Energia. Brasil. 2010 [in Portuguese]. [cited 2014 Jul 21].

161.World Health Organization. Preventing disease through healthy environments: Towards an estimate of the environmental burden of 
disease. WHO; Geneva, 2006. [cited 2015 Jun 13].

Available

from: http://www.who.int/quantifying_ehimpacts/publications/ preventingdisease/en/.

162.Centers for Disease Control and Prevention. Parasites-Ascaridiases. In: Global Health - Division of Parasitic Diseases and Malaria. CDC; Atlanta, USA, 2013. [cited 2014 May 10]. Available from: http://www. cdc.gov/parasites/ascariasis/epi.html.

163.Kronemberger D. Análise dos Impactos na Saúde e no Sistema Único de Saúde Decorrentes de Agravos Relacionados a um Esgotamento Sanitário Inadequado dos 100 Maiores Municípios Brasileiros no Período 2008-2011. 2013. Relatório Final 1-74. [in Portuguese]. [cited 2014 Jun 18]. Available from: http://www. tratabrasil.org.br/datafiles/uploads/drsai/Relatorio-Final-TrataBrasil-Denise-Versao-FINAL.pdf.

164.Brazil. Ministry of the Cities. Sistema Nacional de Informações sobre Saneamento: Diagnóstico dos Serviços de Água e Esgotos. Brasília, 2012. [in Portuguese]. [cited 2014 Feb 18].

165.Brazil. Ministry of the Cities. Brazilian National Plan for Basic Sanitation. Brasília, 2013. [cited 2014 Feb 14].

166.D’Amato G, Cecchi L, D'Amato M, Annesi-Maesano I. Climate change and respiratory diseases. Eur Respir Rev. 2014;23:161-169. doi:10.1183/09059180.00001714.

167.Ignotti E, Hacon SS, Silva AMC, Junger WL, Castro H. Effects of biomass burning in Amazon: method to select municipalities using health indicators. Rev. bras. epidemiol. 2007;10(4):453-464. doi: 10.1590/ S1415-790X2007000400003.

168.Ignotti E, Valente JG, Longo KM, Freitas SR, Hacon SS, et al. Impact on human health of particulate matter emitted from burnings in the Brazilian Amazon region. Rev. Saude Publica. 2010;44(1):121-130. doi:10.1590/S0034-89102010000100013.

169. Oliveira BFA, Ignotti E, Artaxo P, Saldiva PHN, Junger WL, et al. Risk assessment of PM2.5 to child residents in Brazilian Amazon region with biofuel production. Environmental Health. 2012;11(64):1-11. doi:1476-069X-11-64.

170.Szidat S, Jenk TM, Synal H-A, Markus Kalberer, Lukas Wacker, et al. Contributions of fossil fuel, biomass-burning, and biogenic emissions to carbonaceous aerosols in Zurich as traced by ${ }^{14} \mathrm{C}$. Journal of Geophysical Research. 2006;111:D7. doi:10.1029/2005JD006590.

171.Cançado JED, Saldiva PHN, Pereira LAA, Lara LBLS, Artaxo P, et al. Impact of sugar cane-burning emissions on the respiratory system of children and the elderly. Environ Health Perspect. 2006;114(5):725729. doi:10.1289/ehp.8485.

172.Parker JD, Akinbami LJ, Woodruff TJ. Air Pollution and Childhood Respiratory Allergies in the United States. Environ Health Perspect. 200;117(1):140-147. doi: 10.1289/ehp.11497.
173.Brazilian Association of Public Health. Abrasco. Um alerta sobre os impactos dos Agrotóxicos na Saúde. Dossiê Abrasco. Parte 1 Agrotóxicos, Segurança Alimentar e Saúde. Abrasco; Brazil, 2012 [in Portuguese]. [cited 2014 Jun 13].

174.Rasier G, Toppari J, Parent AS, Bourguignon JP. Female sexual maturation and reproduction after prepubertal exposure to estrogens and endocrine disrupting chemicals: A review of rodent and human data. Mol Cell Endocrinol. 2006;254-255:187-201. doi: 10.1016/j. mce.2006.04.002.

175.Centers for Disease Control and Prevention. Lead. In: National Center for Environmental Health, Division of Emergency and Environmental Health Services. CDC; Atlanta, USA, 2014.

176.Bose-O'Reilly S, McCarty KM, ScD, Steckling N, Lettmeier B. Mercury Exposure and Children's Health. Curr Probl Pediatr Adolesc Health Care. 2010;40(8):186-215. doi: 10.1016/j.cppeds.2010.07.002.

177.Kumari M, Ghildiyal R. Clinical Profile of Plasmodium vivax Malaria in Children and Study of Severity Parameters in relation to Mortality: A Tertiary Care Centre Perspective in Mumbai, India. Malaria Research and Treatment. 2014;2014:765657. doi:10.1155/2014/765657.

178.Medronho RA, Macrini L, Novellino DM, Lagrotta MT, Câmara VM, et al. Aedes aegypti immature forms distribution according to type of breeding site. Am J Trop Med Hyg. 2009;80(3):401-404.

179.Brazil. Ministry of Health. Protocolo de vigilância e resposta à ocorrência de microcefalia. Emergência de Saúde Pública de Importância Nacional. [in Portuguese]. Brasília, 2016. 2016 Mar 13]. Available from: http://portalsaude.saude.gov.br/ images/pdf/2016/janeiro/22/microcefalia-protocolo-de-vigilanciae-resposta-v1-3-22jan2016.pdf.

180.World Health Organization. WHO Director-General summarizes the outcome of the Emergency Committee regarding clusters of microcephaly and Guillain-Barré syndrome. WHO; Geneva. 2016.

181.European Centre for Disease Prevention and Control. Zika virus disease epidemic: potential association with microcephaly and Guillain-Barré syndrome (first update). ECDC; European Union. 2016.

182.Mlakar J, Korva M, Tul N, Popović M, Poljšak-Prijatelj M, et al. Zika Virus Associated with Microcephaly. N Engl J Med. 2016;374:951-958. doi:10.1056/NEJMoa160065.

183.Besnard M, Lastère S, Teissier A, V M Cao-Lormeau VM, Musso D. Evidence of perinatal transmission of Zika virus, French Polynesia. Euro Surveill. 2014;19(13):pii=2075. doi: 10.2807/1560-7917. ES2014.19.13.20751. 